32 ( 2 ) : 145 176, 1982

\title{
電子顕微鏡による正常および去勢ラット顎下腺導管系の 形態学的および形態計測的研究
}

\author{
四分一泉 \\ 群馬大学内分泌研究所形態学部門 (主任：黑住一昌教授)
}

(昭和57年 1 月 8 日 受付)

従来より，ある種の蛪歯目顎下腺の導管部には, 性による二様性 (sexual dimorphism) の存在するこ とが知られている。特に実験用のマウスとラットお よび八ムスターの 3 種は, その他の踾歯目の動物に 比べ食習慣，水分攝取の条件等が一定していて，個 体差の発現が少く，普遍的な研究成績が得られ易い ため数多くの研究者によって報告されている。中で も実験用マウスは，顎下腺の性差が顕著であるため 最も多〈研究されている(13)13/21)27).このようなマウ 又顎の顎下腺に見られる性差は性ホルモンの作用 によって発現することが，まず光学顕微鏡によって 示されたが, 近年になると, 電子顕微鏡によってマウ ス下腺の導管を構成する個々の細胞に顕著な雌雄差 の存在することが示された ${ }^{4)}$. $\left(\right.$ aramia ${ }^{5)}$ の研究によ ると雄マウスの去勢によって形態学的に完全に雌に 一致するようになるわけではないというが，最近で は雄のマウスの去勢によって, 顎下腺の amylase 活 性が雌のそれに一致することが示された ${ }^{27)}$.

一方，ラットの顎下腺の性差に関する研究は，マ ウスにおけるほどは多くはない。当初，ラット顎下 腺の雌雄差は組織学的には認識できないとされた $か^{(2) 2126)}$,ラット顎下腺の amylase 活性に雌雄差の発 現することは比較的早期より知られていた ${ }^{28)}$.

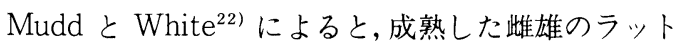
の顎下腺を比べると雄の場合は, 腺房と果粒性膨大 部との比率がほとんど 1：1であるのに対し, 雌で はその比率がおよそ2：1である。さらに成熟ラッ トに比へ，生後35日の幼若ラットの場合には形態学 的性差は発現せず，果粒性膨大部の占める比率は雌 雄ともに少く, 性的成熟の後に顎下腺の性差が発現 することが明らかとなった。

筆者は, 正常雌雄のラット顎下腺の導管系の超微 細構造を比較観察し, 腺房と果粒性膨大部の比率, すなうち果粒性膨大部の発達程度において雌雄差が
存在するのみならず, 導管系を構成する個々の細胞 に性差の存在することを確認した。ささらに成熟雄 ラットを去勢し，導管系におよぼす影響について若 干の知見を得たのでここに報告する。

\section{材 料と方 法}

成熟した雌と雄のウィスター系ラット，および同 系の成熟雄の去勢後 4 か月目のラットを断頭により 屠殺し，顎下腺の小片を採取した。採取した小片は さらに $4^{\circ} \mathrm{C}$ に泠却した固定液中ですみやかに約 1 $\mathrm{mm}^{3}$ の大きさに細切された。

試料は下記による二重固定法によって固定され た. 細切された試料は, 最初に $2 \%$ グルタール・ア ルデヒドと $2 \%$ パラフォルム・アルデヒドを含む $\mathrm{pH} 7.2$ に調整した $0.2 \mathrm{M}$ 燐酸緩衝液中に約 2 時間浸 漬した。次いで試料を $0.2 \mathrm{M}$ 燐酸緩衝液にて充分に洗 滌した後, 1 \%四酸化オスミウムを含む $\mathrm{pH} 7.2$ の燐 酸緩衝液中に 1 時間浸漬した。試料の一部は, さら に $1.5 \%$ 酰酸ウランに24時間浸漬し,ブロック染色を 行ない，残りはそのまま脱水した。すなわちブロッ ク染色を施した試料も，これを施さない試料も，い ずれも上昇アルコール系列を通して脱水し,さらに プロピレンオキサイド中に浸漬した。

脱水を終了した試料は, エポン 812 とアラルダイト の混合包埋剂に包埋され, $37^{\circ} \mathrm{C}$ に数日間脬置して重 合固化された。電子顕微鏡用の試料は, Porter-Blum MT-2B 超ミクロトームによって薄切した。 超薄切片は直ちに銅グリッドに張り付け，酢酸ウラ ンとクエン酸鉛の二重染色を施した。

試料の観察には, 日立の透過型電子顕微鏡 HU-11D 型を用い, $75 \mathrm{KV}$ の加速電圧下で観察撮影を行 なった。

分泌果粒の面積測定のためには10,000倍に引伸し た電子顕微鏡写真について, Kontron 製 MOP/AM 
01 を用いて, 細胞質面積を自動的に測定し, 果粒面 積は同機の point counting system を用いて測定 し, 細胞質面積に対する百分比として算出した。

\section{所見}

\section{I 正常雌ラット顎下腺}

A 介在部 (Intercalated duct)

1）介在部の形状

介在部は，一方では腺房に結合し，他方は線条部 に結合する導管系の初部に相当する部分である.介 在部の外周は, 長い突起を有する三角形あるいは星

表 1 ラット顎下腺導管各部の大きさ $(\mu \mathrm{m})$ A

\begin{tabular}{c|c|c|c}
\hline \multirow{2}{*}{} & \multicolumn{2}{|c}{$介$} & \multicolumn{2}{c}{ 在 } & \multicolumn{2}{c}{ 部 } \\
\cline { 2 - 4 } & 正 常 雄 & 去 勢 雄 & 正 常 雌 \\
\hline 導管の外径 & $20.34 \pm 8.28$ & $21.19 \pm 6.58$ & $26.61 \pm 5.43$ \\
\hline 導管の内径 & $6.57 \pm 3.83$ & $5.40 \pm 3.42$ & $4.26 \pm 1.38$ \\
\hline 管壁の厚さ & $9.07 \pm 4.16$ & $8.48 \pm 2.52$ & $8.63 \pm 2.78$ \\
\hline
\end{tabular}

B

\begin{tabular}{c|c|c|c}
\hline \multirow{2}{*}{} & \multicolumn{2}{|c}{ 線 } & \multicolumn{2}{c}{ 条 } & \multicolumn{1}{c}{ 部 } \\
\cline { 2 - 4 } & 正 常 雄 & 去 勢 雄 & 正 常 雌 \\
\hline 導管の外径 & $27.43 \pm 11.91$ & $39.83 \pm 9.28$ & $36.14 \pm 14.05$ \\
\hline 導管の内径 & $2.78 \pm 2.95$ & $4.46 \pm 0.31$ & $4.37 \pm 2.47$ \\
\hline 管壁の厚さ & $15.84 \pm 2.58$ & $17.03 \pm 3.21$ & $15.40 \pm 6.65$ \\
\hline
\end{tabular}

C

\begin{tabular}{c|c|c|c}
\hline \multirow{2}{*}{} & \multicolumn{3}{|c}{ 果 粒 性 膨 } \\
\cline { 2 - 4 } & 正 常 雄 & 去 勢 雄 & 正 常 雌 \\
\hline 導管の外径 & $56.83 \pm 13.00$ & $50.85 \pm 9.00$ & $44.00 \pm 15.65$ \\
\hline 導管の内径 & $10.23 \pm 3.88$ & $8.39 \pm 4.10$ & $4.25 \pm 2.97$ \\
\hline 管壁の厚さ & $24.35 \pm 4.41$ & $23.03 \pm 3.79$ & $19.78 \pm 7.75$ \\
\hline
\end{tabular}

D

\begin{tabular}{|c|c|c|c|}
\hline & 排 & \multicolumn{2}{|r|}{ 管 } \\
\hline & 正 常 雄 & 去 勢 雄 & 正 常 雌 \\
\hline 導管の外径 & $50.08 \pm 0.81$ & $82.73 \pm 4.48$ & $121.43 \pm 14.53$ \\
\hline 導管の内径 & $10.72 \pm 0.11$ & $30.60 \pm 6.92$ & $53.54 \pm 20.12$ \\
\hline 管壁の厚さ & $21.01 \pm 1.38$ & $27.71 \pm 5.75$ & $28.80 \pm 3.95$ \\
\hline
\end{tabular}

状を呈することが多い，介在部は，腺房や他の導管 の間隙を充填するために，そのような形態をとるの である. 介在部の外径は, 最大 $34.0 \mu \mathrm{m}$, 平均 $26.6 \pm$ $5.43 \mu \mathrm{m}$ であり, 内径は, 最大 $7.0 \mu \mathrm{m}$, 平均 $4.3 \pm 1$. $4 \mu \mathrm{m}$ であった（表 $1 \mathrm{~A}$ ).

前述のごとく介在部は腺房に隣接する導管系の初 部であるから, 両者の移行部においては腺房細胞が 介在部の細胞と一つの管腔を共有している(図 1 ).

上記の例においては腺房細胞と介在部細胞との接 触面は一般に滑らかであるが, 指状嵌合を伴う所も 認められる。むしろ介在部の細胞同士の接する面の 方が，明瞭な指状嵌合を有して，不規則な境界線を 生ずる.

2）細胞の形と核の外形

介在部の細胞基底部の外周は, 比較的滑らかで基 底陥入は, ほとんど認められない.介在部の細胞は, おおむね扁平で小さく, 細胞の高さは最小 $5.0 \mu \mathrm{m}$, 最大 $11.3 \mu \mathrm{m}$, 平均 $7.6 \pm 1.92 \mu \mathrm{m}$ で, 細胞の幅は最 小 $4.0 \mu \mathrm{m}$, 最大 $10.2 \mu \mathrm{m}$, 平均 $7.4 \pm 1.62 \mu \mathrm{m}$ であっ た。介在部細胞の核は, 細胞の大部分を占めること が多い. 核の大きさは, 長軸が最大 $12.0 \mu \mathrm{m}$, 平均 5 . $9 \pm 2.10 \mu \mathrm{m}$, 短軸は最大 $6.0 \mu \mathrm{m}$, 平均 $3.2 \pm 1.32 \mu \mathrm{m}$ であった。核の外形と細胞の外形とは類似する場合 が多く, 扁平な細胞では核も扁平で, その長軸は細 胞の長軸方向に位置している.

3）介在部細胞の先端部

介在部の管腔は介在部全体の太さに比べると割合 太く, 内腔は微細粒状物質で満されている。隣りあ う細胞同士の接触面のうち, 管腔に最も近いところ に密着帯がみられる。ささらに梁いところには接着斑 が存在し，これらの部分の肥厚した細胞膜に細い系 状物質が付着している(図2). 管腔面からしばしば 短い微絨毛が突出している．腺房の微䋐毛は部分に よっては欠除している場合が多くみられるし，また その数も少いのに対し, 介在部の微絨毛は, 比較的 数が多いのが特徵である.大多数の微絨毛は, 0.3 $\sim 0.5 \mu \mathrm{m}$ の長さを有する.

4）介在部細胞の分類

介在部を構成する細胞には以下の 3 型が存在す る.

a) 暗調細胞 (dark cell)

b ) 果粒細胞 (granulated cell)

c) 筋上皮細胞 (myoepithelial cell)

a ) 介在部暗調細胞 
暗調細胞は, 介在部細胞の中では最も頻繁にみら れるもので, 細胞質は暗く, 分泌果粒を含まない(図 2 ). 暗調細胞と果粒細胞との数の比率は, おおむね 5：2である。暗調細胞は細胞の大きさが小さく, さらに核と細胞質の比が大きいため細胞は，はなは だ狭小である。糸粒体の発達は貧弱で，小さいもの が多く，その長さは， $0.5 \mu \mathrm{m}$ 内外のものが多い.

b ) 介在部果粒細胞

果粒細胞は，前述の暗調細胞と異なり分泌果粒を 有し, 細胞質の電子密度は比較的低いのが特徵であ る(図 3 ). 暗調細胞の大部分が管腔面を有している のに比し, 果粒細胞はその半数のみが管腔面を有し, 残りの半数は管腔面を有しなかった。しかし，この 細胞に含まれる分泌果粒は開口様式により分泌され ると思われるから，この細胞は必ずどこかで管腔に 接しているはずである。管腔面を有する細胞の中に は, $1.0 \mu \mathrm{m}$ 以上の比較的長い微絨毛を有するものも あるが, $0.3 \mu \mathrm{m}$ 内外の微絨毛を有するものがきわめ て多い.

果粒細胞の管腔面から細胞質内に微䋐毛をもった 細管が陥入して細胞内分泌細管を形成している。た とえ果粒細胞が直接管腔に接触していなくても, 細 胞内分泌細管によって，かなり広い部分が管腔に接 続することが可能となる.

細胞の大きさについては, 高さは最大 $17 \mu \mathrm{m}$, 平均 $7.9 \pm 3.6 \mu \mathrm{m}$, 細胞の幅は最大 $15 \mu \mathrm{m}$, 平均 $7.4 \pm 1.62$ $\mu \mathrm{m}$ であった。暗調細胞を含めた介在部の平均值に 比し, 幅の広い傾向がみられる，細胞の外形は表面 の平滑な球形を呈している。また暗調細胞では，ほ とんど全ての細胞に核が認められたが，果粒細胞で は横断面上に核のみられなかったものが，約半数を 占める。このことは, 果粒細胞の核は, その細胞質 の体積に比して小さいということを示唆する．核の 観察できたもののうち,大きいものは, $9.0 \times 6.0 \mu \mathrm{m}$ 程度で, 平均は $(5.98 \pm 1.66) \times(3.75 \pm 1.47) \mu \mathrm{m}$ であり，核の大きさには介在部全体の平均に比し有 意の差は認められなかった。

系粒体の発達は不良で, 長いものは $1.0 \mu \mathrm{m}$ 程度 で, 平均が $(0.68 \pm 0.21) \times(0.36 \pm 0.12) \mu \mathrm{m}$ で 数は少く，暗調細胞との間に有意の差はなかった。

果粒細胞の分泌果粒は腺房のそれとは明らかに異 なり，果粒性膨大部の果粒には電子密度が類似する けれども，大きさは異なる，分泌果粒は 1 細胞断面 に多いもので46個含まれ，少ないもので 9 個，平均
すると $25.6 \pm 13.8$ 個含まれる. 分泌果粒の大きさは ほほ均一で大きさの変異は比較的少なかった。直径 は最小 $0.22 \mu \mathrm{m}$, 最大 $0.68 \mu \mathrm{m}$, 平均 $0.46 \pm 0.33 \mu \mathrm{m}$ であった。個々の分泌果粒の電子密度には若干の変 異があるけれども，いずれの分泌果粒も限界膜を有 し，その内容は均一性で，ただ 1 種類の分泌果粒と 考えられる。

\section{C ）筋上皮細胞}

介在部に付着する筋上皮細胞は比較的多くみられ る。その中では明らかに介在部に属すると思われる ものと, 隣接する腺房と介在部の中間にあり, 所属 の明らかでないものとがある．筋上皮細胞は, 多く の場合介在部の周囲に並んでいるが, 時には約 $13 \mu \mathrm{m}$ 程の長い細胞質突起が介在部に続く線条部の周 囲までも包んでいることがある(図 4 ). 筋上皮細胞 の核は長軸を基底面に平行に向けており，長いもの では $13.0 \times 2.5 \mu \mathrm{m}$, 図 4 では $6.3 \times 0.7 \mu \mathrm{m}$ である. 核の電子密度は暗調細胞の核よりもわずかに低い。 筋上皮細胞の細胞質の電子密度は, 暗調細胞より若 干低い. 細胞質内には多数の筋細系 (myofilaments) が存在する．その走向は細胞長軸に一致している。 細胞小器官の発達は不良である。筋上皮細胞は管腔 に接していないため, 密着帯は認められないが, 接 着斑は隣接する暗調細胞との間に存在する.

\section{B 線条部 (Striated duct)}

1）線条部の形状

線条部の初部は介在部から連続し, 終部は排出管 一接合する。介在部との接合に際し，介在部が線条 部の側壁へ結合する側面結合が観察された。また盖 歯目の顎下腺では線条部の一部が大きい分泌果粒を 有する果粒性膨大部となっているが, 前者の中に後 者の構成細胞が混在している所がみられた（図 5 ). 線条部の横断像の外周は円形ないし楕円形を呈して いる。線条部の外径は最小約 $20 \mu \mathrm{m}$, 最大 $60 \mu \mathrm{m}$ ，平 均 $36.1 \pm 14.05 \mu \mathrm{m}$ で, 介在部より明らかに大きい. 導管全体の大きさに対して内径が小さいのが線条部 の一つの特徵であり, 最小 $2.0 \mu \mathrm{m}$, 最大 $10.0 \mu \mathrm{m}$, 平 均は $4.37 \pm 2.47 \mu \mathrm{m}$ であり, 介在部の内径と同程度 である（表 $1 \mathrm{~B}$ )。また線条部には細胞基底面より管 腔に向ってほぼ垂直に基底線条がみられる。

基底線条とよばれるものは，よく発達した形質膜 の基底陥入とこれに平行して分布する発達の良い長 桿状の系粒体とから形成される. 大部分の細胞の先 
端は管腔に面し，基底面の広い円錐状を呈する（図 6 ).細胞の大きさは基底面に垂直な方向を高さとし た場合, 最小 $9.0 \mu \mathrm{m}$, 最大 $23.0 \mu \mathrm{m}$, 平均 $14.6 \pm 4.21$ $\mu \mathrm{m}$ で, 細胞の幅は最小 $7.0 \mu \mathrm{m}$, 最大 $22.0 \mu \mathrm{m}$, 平均 $12.9 \pm 4.74 \mu \mathrm{m}$ である。

2) 細胞の核

核の位置は細胞長軸の中心よりやや基底側寄りに あり, 基底面より測定すると平均 $6.8 \pm 2.40 \mu \mathrm{m}$ の位 置にある.核の大きさは, 最小 $3.0 \times 2.0 \mu \mathrm{m}$, 最大 7.0 $\times 6.0 \mu \mathrm{m}$, 平均 $(4.9 \pm 1.44) \times(4.0 \pm 1.06) \mu \mathrm{m}$ である。外形は球形から基底側に垂直な方向へ長軸 を向ける楕円形を呈する。核の外周は平滑であり核 内にはへテロクロマチン様構造がみられ, 核小体は, やや電子密度が高く直径は0.5 1.5 $\mathrm{m}$ ほどであ る。個々の細胞が互いに接触する面の管腔に最も近 い部分には密着带が頻繁にみられた。ささらに細胞外 側面のやや深いところには中間帯が観察される。線 条部細胞の細胞質の電子密度は比較的低いが細胞質 の電子密度の高い暗調細胞もみられる(図6).しか し両者の間には基本的差異は認められない。という のは暗調細胞といっても細胞質の電子密度の変異に は種々の段階があって中間的な細胞も存在するから である、線条部における明調細胞と暗調細胞の分布 状態は，前者の方がはるかに優性である。

3）細胞の先端部

細胞先端部では管腔に向って微絨毛が突出してい るのがみられる.微絨毛の長さは約 $0.5 \sim 1.0 \mu \mathrm{m} て ゙$, 短いものが大多数である。管腔面に，いわゆる ballooning 現象は観察されなかった. 管腔面より, 細 胞内部へおよそ1〜6 $4 \mathrm{~m}$ 程の限局された範囲に, 多数の小さい分泌果粒が存在し, これは線条部のほ とんどすべての細胞先端部において認められた。こ の分泌果粒には, 電子密度の高い暗調果粒と, 電子 密度の低い空胞状の明調果粒の 2 種類が認められ た。暗調果粒は, 明調細胞および暗調細胞の双方に 存在する。明調果粒は, 多くの場合暗調細胞に存在 するが(図 5 ), 明調細胞にも含まれる場合がある。 明調果粒は, 暗調果粒とは区別して考える必要があ るため, 両者を別個に計測した。分泌果粒のうち多 く存在する暗調果粒は, 1 細胞断面に平均 $14.7 \pm 8$. 75 個存在し, 直径は $0.2 \pm 0.02 \mu \mathrm{m}$ である.一方の明 調果粒は, 1 細胞断面に $10.0 \pm 3.56$ 個で, 直径は 0 . $5 \pm 0.13 \mu \mathrm{m}$ と暗調果粒よりやや大きかった。

4）細胞の基底部
細胞の基底部には強い基底陥入が認められる。基 底陥入の高さは基底面より測定すると, 高い部分で 約 $5.6 \mu \mathrm{m}$ ，中間の部分で $4.5 \mu \mathrm{m}$ ，低い部分は約 3.0 $\mu \mathrm{m}$ に達し, 細胞の高さに対し基底部から,およそ 1/3〜1/2に達している。また線条部の暗調細胞と明 調細胞が隣りあう所には指状嵌合を容易に指摘でき る(図6).

5) 系粒体

系粒体の発達は導管系の中では線条部が最も高度 である。特に基底部では，基底線条の走向に一致し た方向に長軸を向けた系粒体が多数認められる。長 さは最大 $18.0 \mu \mathrm{m}$, 平均 $1.7 \pm 0.59 \mu \mathrm{m}$ である。細胞 先端部付近の系粒体は比較的短く, 平均で $(0.88 \pm$ $0.19) \times(0.5 \pm 0.10) \mu \mathrm{m}$ である. 基底部と先端部 の系粒体を比較すると, 長軸では基底部の方がおよ そ2 倍程長く, 短軸は双方とも差異がなかった。

\section{C 果粒性膨大部 (Granular duct)}

击藏目顎下腺に通常の線条部と異なる導管が存在 することは従来より報告されており，果粒管または 果粒性膨大部と呼ばれている。また果粒性膨大部は, 珁菌目以外の七トを初めとする哺乳類の多くにはみ られないことから，線条部の一部が変化したものと 考えられている. 特にラットの顎下腺では雌雄差が 大きく, 雄の顎下腺では線状部よりむしろ果粒性膨 大部の占める割合が優位であるのに対し，雌の場合 は線条部の方が優位である。

1）果粒性膨大部の形状

果粒性膨大部の外形は横断面で円形ないし棈円形 を呈し，線条部より概して太いものが多い。果粒性 膨大部の外径は最大 $69.0 \mu \mathrm{m}$, 平均 $44.0 \pm 15.65 \mu \mathrm{m}$ である。導管の内径は比較的小さく最大 $9.0 \mu \mathrm{m}$, 平 均は $4.3 \pm 2.97 \mu \mathrm{m}$ である。導管の厚さは最大 33.0 $\mu \mathrm{m}$, 平均 $19.8 \pm 7.75 \mu \mathrm{m}$ である (表 $1 \mathrm{C}$ ). 果粒性 膨大部の細胞のうち多くのものは，管腔面を有して いる。しかし，線条部の細胞では，その大部分が管 腔面を有するのに比し，果粒性膨大部においては管 腔に面しない細胞も多くみられた。しかし切片の面 上において管腔面が認められなくても，他の部分で 管腔に接している可能性は十分にある。果粒性膨大 部の細胞は, その大きさ, 細胞質の電子密度, 細胞 小器官の発達状態, 核の形, 核の位置, さらに分泌 果粒の形態において多様性に富んでいる. Tamarin と Sreebny ${ }^{30)}$ の分類を参考にし,これに基底細胞と 
明調狭細胞を加え，以下のように区分を行なった。

I 型 基底細胞 (basal cell)

II 型 暗調狭細胞 (dark narrow cell)

III型 明調狭細胞 (light narrow cell)

IV 型 明調果粒細胞 (light granular cell)

V型 暗調果粒細胞 (dark granular cell)

今回計測を行なった細胞のうち 5 種の細胞の出現 頻度は表 2 の通りである。

表 2 ラット顎下腺果粒性膨大部の各細胞型の出現頻度 $\%$ (個数)

\begin{tabular}{|c|c|c|c|c|c|}
\hline & 基底細胞 & $\begin{array}{lll}\text { 暗 } & \text { 調 } \\
\text { 狭 細 胞 }\end{array}$ & $\begin{array}{ll}\text { 明 } & \text { 調 } \\
\text { 狭 細 胞 }\end{array}$ & $\begin{array}{l}\text { 明 調 } \\
\text { 果粒細胞 }\end{array}$ & $\begin{array}{l}\text { 暗 調 } \\
\text { 果粒細胞 }\end{array}$ \\
\hline 正常雄 & $\begin{array}{r}13.6 \\
(11)\end{array}$ & $\begin{array}{c}4.9 \\
(4)\end{array}$ & $\begin{array}{r}2.5 \\
(2)\end{array}$ & $\begin{array}{r}24.7 \\
(20)\end{array}$ & $\begin{array}{l}54.3 \\
(44)\end{array}$ \\
\hline 去勢雄 & $\begin{array}{r}5.7 \\
(8) \\
\end{array}$ & $\begin{array}{r}2.1 \\
(3) \\
\end{array}$ & $\begin{array}{r}2.8 \\
(4) \\
\end{array}$ & $\begin{array}{l}8.5 \\
(12) \\
\end{array}$ & $\begin{array}{c}80.9 \\
(114) \\
\end{array}$ \\
\hline 正常雌 & $\begin{array}{l}10.0 \\
\quad(5)\end{array}$ & $\begin{array}{r}16.0 \\
(8)\end{array}$ & $\begin{array}{r}16.0 \\
(8)\end{array}$ & $\begin{array}{l}24.0 \\
(12)\end{array}$ & $\begin{array}{r}34.0 \\
(17)\end{array}$ \\
\hline
\end{tabular}

\section{2）基底細胞}

基底細胞は腺上皮の基底部に偏して存在し, 細胞 先端部は腺腔に面せず，分泌果粒は認められない。 また線条部の細胞とは明らかに異なり，基底線条を 欠いている(図 7 )。細胞は概して低く，カマボコ形 の断面を示し, 高さは平均 $10.4 \pm 4.29 \mu \mathrm{m}$, 幅は最小 $8.6 \mu \mathrm{m}$, 最大 $24.7 \mu \mathrm{m}$, 平均 $14.6 \pm 6.24 \mu \mathrm{m}$ であっ た。核の直径は， $(5.1 \pm 1.52) \times(4.9 \pm 1.88) \mu \mathrm{m}$ で，ほほ球形であり，核の外周は滑らかである。細 胞質の電子密度はやや高い傾向にある。系粒体の発 達は比較的良好であるが, 長桿状の長いものは，あ まり多くみられず,多くは球形から棈円形を呈する. 系粒体の大きさは平均 $(1.0 \pm 0.36) \times(0.4 \pm 0.17)$ $\mu \mathrm{m}$ である.

3）暗調狭細胞

細胞の面積は狭く，上皮基底面に対して垂直に縦 に長い形を呈している。細胞の高さは最大 $25.0 \mu \mathrm{m}$, 平均 $14.8 \pm 5.40 \mu \mathrm{m}$ である。細胞の幅は最小 $6.0 \mu$ $\mathrm{m}$, 最大 $21.0 \mu \mathrm{m}$, 平均 $6.8 \pm 2.88 \mu \mathrm{m}$ で他のいずれ の型と比しても狭い。

細胞質には, 遊離リボゾームが多く存在し, 細胞 質の電子密度は高い.核は比較的小さく最大 $6.0 \times 8$. $0 \mu \mathrm{m}$, 平均 $(4.9 \pm 1.81) \times(3.4 \pm 0.86) \mu \mathrm{m}$ であ $\eta$ ，長軸を細胞体の長軸方向に向けている，核の位 置は細胞質の中央の部分よりやや管腔寄りに位置し
ている，細胞先端部で腺腔に面する部分には，長さ 0.2 0.5 $\mu \mathrm{m}$ の微絨毛が突出している (図 8 ). 系粒 体は, 細胞基底部から細胞先端部にかけて広い範囲 に存在するが，数は少く大きさも小さいものが大部 分である，すなわち最大 $3.0 \times 1.0 \mu \mathrm{m}$ で，平均は基 底部付近で $(1.2 \pm 0.86) \times(0.4 \pm 0.81) \mu \mathrm{m}$, 先端 部では $(1.0 \pm 0.54) \times(0.6 \pm 0.35) \mu \mathrm{m}$ であった。 暗調狭細胞は多くの場合, 分泌果粒を含まないが, 先端部付近に分泌果粒を有することがある（図 9 ). 分泌果粒には，電子密度の高い小さい球状を呈する 暗調果粒と電子密度の低い外形不正の明調果粒の 2 型がある。明調果粒は, 1 細胞断面に平均 10 個存在 し, 直径は $0.8 \pm 0.47 \mu \mathrm{m}$ であった。暗調果粒は平均 2.5 個存在し, 直径は $0.3 \pm 0.05 \mu \mathrm{m}$ であった。

\section{4）明調狭細胞}

果粒性膨大部の細胞のうち, 細胞質の電子密度が 低く分泌果粒は比較的少く, 細胞の幅の狭いものを 明調狭細胞として分類した。明調狭細胞の高さは最 大 $35 \mu \mathrm{m}$, 最小 $8.0 \mu \mathrm{m}$, 平均は $10.4 \pm 3.97 \mu \mathrm{m}$ であっ た（図10）。

核は比較的大きく, 最大 $9.0 \times 7.0 \mu \mathrm{m}$ で, 平均 (6.7 \pm 1.98$) \times(6.4 \pm 2.25) \mu \mathrm{m}$ であった. 核の形は 球形ないし楕円形を呈し, 核の上面の圧迫傾向は認 められない。核の位置は, 細胞の中央部に位置する ものが多く, 細胞基底面から核中心部までの距離は 平均 $8.0 \pm 2.49 \mu \mathrm{m}$ であった。

系粒体は比較的良く発達しており，核下方から基 底部にかけて特に数が多い。また核上部にも良く発 達した糸粒体がみられる。このような核上部の良く 発達した糸粒体は, 明調果粒細胞および暗調狭細胞 には見られない現象である（図10）。

系粒体の大きさは細胞基底部と先端部とでは，若 干の差があり，基底部により良く発達した系粒体が 多くみられる。平均すると基底部で $(1.3 \pm 0.46) \times$ $(0.6 \pm 0.17) \mu \mathrm{m}$, 先端部で $(1.1 \pm 0.43) \times(0.6 \pm$ 0.16) $\mu \mathrm{m}$ である.

分泌果粒は, 電子密度の低い明調果粒, 形の小さ い電子密度の高い小暗調果粒, および大きく電子密 度の高い大暗調果粒の 3 種類が認められる. 分泌果 粒の数は少く, 特に大暗調果粒は認められないこと が多い。分泌果粒は, 明調果粒が 1 細胞断面に平均 $16.8 \pm 12.47$ 個存在し, 直径は $1.0 \pm 0.31 \mu \mathrm{m}$ であり, 小暗調果粒は平均 $7.5 \pm 6.09$ 個存在し, 直径は $0.3 \pm$ $0.03 \mu \mathrm{m}$ であり, 大暗調果粒は平均 1.0 個存在し, 直 
径は $1.3 \pm 0.27 \mu \mathrm{m}$ であった。

明調狭細胞の分泌果粒の中には，明るい空胞の内 部に電子密度の高い小粒子が不規則に分散している ものがある。このような不均質な果粒はこの細胞に おいてのみ発見され，また稀に認められるに過ぎな い(図10).

粗面小胞体の発達は比較的良好である。

5) 明調果粒細胞

明調果粒細胞は明調狭細胞と同様に細胞質の電子 密度が低く，分泌果粒の形が大きく，数も多く，か つ大暗調果粒の数より明調果粒の数が優位にあるも のを明調果粒細胞として分類した。

明調果粒細胞は，明調狭細胞に比し，細胞は大き く, 細胞の高さは最大 $30.0 \mu \mathrm{m}$, 平均 $19.1 \pm 6.95 \mu \mathrm{m}$, 細胞の幅は最大 $32.1 \mu \mathrm{m}$, 平均 $15.6 \pm 7.98 \mu \mathrm{m}$ で, わ ずかながら高さの方が幅に優っている.

核の大きさは, 平均 $(6.3 \pm 1.78) \times(6.5 \pm 2.12)$ $\mu \mathrm{m} て ゙$, ほぼ球形を呈し, 明調狭細胞と有意の差はな かった。核の位置は基底面からの平均距離 $6.8 \pm 3.20$ $\mu \mathrm{m}$ で，これは細胞の高さに対し基底部より約 $1 / 3$ 程度の位置にある。核の外周は比較的平滑である が，核の上縁は分泌果粒による圧迫のために陥凹が 認められることがある（図10）。

系粒体は良く発達しているが，明調狭細胞のよう に細胞質全域にわたり広く発達しているのではな く, 明調果粒細胞の場合は, 先端部は果粒によって 占められるので, 系粒体は主として核下部, 核側部 一圧排されている。系粒体の大きさは, 基底部で平 均 $(1.4 \pm 0.56) \times(0.6 \pm 0.17) \mu \mathrm{m}$, 先端部では

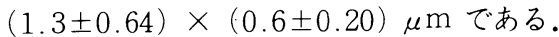

分泌果粒は主に外形不正な球形で空胞状を呈し, 電子密度の低いものが多いが, 大小 2 種の暗調果粒 も少数混在している(図10). 明調果粒細胞の 1 細胞 断面の分泌果粒の個数は, 明調果粒が $19.2 \pm 7.44$ 個 で, 小暗調果粒は8.9 0.24 個で, 大暗調果粒は全く 含まれない細胞もあったが, 平均 $3.6 \pm 1.89$ 個であっ て, 各果粒型の中で最少である。平均直径は, 明調 果粒が $1.2 \pm 0.63 \mu \mathrm{m}$, 小暗調果粒が $0.2 \pm 0.06 \mu \mathrm{m}$, 大暗調果粒 $1.3 \pm 0.53 \mu \mathrm{m}$ であった。明調果粒の内容 は電子密度にやや変異があり, 非常に明るいものと, 中等度の電子密度のものの間に種々の段階のものが 混じている。また空腔内に小胞状の物体を含むもの がある（図10，11）。

管腔面より突出する微絨毛の発達は概して不良で
あり， $0.5 \mu \mathrm{m}$ 内外であるが，長いものでは， $1.7 \times$ $0.4 \mu \mathrm{m}$ に達するものがみられた（図11）。また，粗 面小胞体，ゴルジ装置の発達は良好である（図10）。

\section{6）暗調果粒細胞}

暗調果粒細胞は, 細胞質の電子密度が高く, 多数 の電子密度のきわ力て高い大型の分泌果粒を主とす るが，明調果粒細胞では，主な分泌果粒であった明 るい外形不正の大型果粒も少数混在する（図12）.

細胞の大きさは, 高さが最大 $27.0 \mu \mathrm{m}$, 平均 $16.7 \pm$ $5.54 \mu \mathrm{m}$, 幅が最大 $19.0 \mu \mathrm{m}$, 平均 $11.9 \pm 5.95 \mu \mathrm{m}$ で ある。

核の位置は基底側へ偏位し，基底面から核の中心 部までの長さを測定すると，平均で $3.8 \pm 1.81 \mu \mathrm{m}$ で, 細胞の高さに対して，およそ下位 $1 / 4$ はどの位置 を占めている。基底陥入はほとんど認められない．

系粒体の発達は, 暗調狭細胞よりも良好であるが, 明調狭細胞および明調果粒細胞よりも少ない．多く は細胞基底部に存在し,大きさは長いものは少なく, 大きいものでも， $1.5 \times 1.0 \mu \mathrm{m}$ に過ぎない，平均は 基底部で $(1.0 \pm 0.31) \times(0.6 \pm 0.20) \mu \mathrm{m}$ で，先 端部が $(0.8 \pm 0.40) \times(0.4 \pm 0.15) \mu \mathrm{m}$ である。 粗面小胞体およびゴルジ装置の発達は良好である が，明調果粒細胞に比べると劣っている（図12）。

分泌果粒の発達は, 果粒性膨大部の細胞の中で最 も良好で, 多〈は細胞先端より基底部へ向う $3 / 4 \sim 4 / 5$ 程の範囲にわたり細胞質の大部分を占めている．分 泌果粒には前述の明調果粒と大暗調果粒に加之, 電 子密度の高い小暗調果粒も存在する。細胞の 1 断面 に含まれる分泌果粒の数を調べると, 明調果粒は暗 調果粒細胞のうち過半数の細胞には含まれていない が,含まれる細胞だけについて平均すると $2.7 \pm 1.37$ 個で最小の出現率を示す。小暗調果粒は，全細胞断 面に存在し，8.1 \pm 5.21 個である。大暗調果粒の出 現率は最大で，これも全細胞断面に存在し，22.1土 10.06個である.分泌果粒の大きさは, 明調果粒が 1.3 $\pm 0.39 \mu \mathrm{m}$, 小暗調果粒が $0.3 \pm 0.07 \mu \mathrm{m}$, 大暗調果粒 は $1.5 \pm 0.47 \mu \mathrm{m}$ である。

D 排出管 (Excretory duct)

排出管は前述の線条部あるいは線条部の変型であ る果粒性膨大部に続く導管系の最終部にあたる部分 である。排出管には, 唾液腺小葉内に存在する比較 的細い導管と腺体から離れた位置に存在し口腔上皮 に近づくにつれ，次第に太くなる大導管とがある. 
本研究では前者の小葉内の排出管について検討し た。

排出管の周囲には豊富な結合組織と毛細血管が存 在する．排出管は線条部に類似しているところもあ るが, 導管の外径が平均 $121.4 \pm 14.53 \mu \mathrm{m}$, 内径も平 均 $53.5 \pm 20.12 \mu \mathrm{m}$ と一般に太いのが特徴となって いる，導管の厚さは平均 $28.8 \pm 3.95 \mu \mathrm{m}$ である（表 $1 \mathrm{D})$.また線条部が単一な細胞から構成されている のに対し，排出管には大別すると， 3 種類の細胞が 存在する。その第 1 は, 高円柱状の細胞で, 細胞質 の電子密度の低い明調円柱細胞 (light columnar cell）である。第 2 は, 明調円柱細胞と同様, 細胞の たけは高いが細胞質の電子密度が高く細胞質内に多 数の小空胞を有する暗調円柱細胞 (dark columnar cell）である。最後は，管腔から遠く離れて導管基底 側に偏位している基底細胞で（basal cell）ある。

1）明調円柱細胞

明調円柱細胞は排出管の中では最も多数出現する 細胞型であり,やや線条部細胞に類似している。細胞 の高さは, $24.7 \pm 4.71 \mu \mathrm{m}$, 細胞の幅は $11.5 \pm 4.00$ $\mu \mathrm{m}$ で，明らかに管腔に垂直な方向に長い円柱状を 呈している.

核の大きさは $(6.7 \pm 1.42) \times(6.3 \pm 1.64) \mu \mathrm{m}$ で 比較的大きくほぼ球形を呈している。核膜の周囲に はリボゾームが付着している，核の位置は基底面よ り，およそ3/5に位置し，むしろ管腔面に近い位置を 占めている。この傾向は他の導管のいずれの細胞に も見られなかった現象である（図13）。

管腔に面している細胞膜の一部には微絨毛の突出 が見られることがあるが，その長さは短く数も少な い. 従って細胞の管腔側の輪郭は平滑である。細胞 質の電子密度は低く線条部の細胞に見られたもの と，ほぼ同程度である．細胞先端部の管腔面に近い 部分では, 隣りの細胞と接するところに密着帯がみ られ，その下方には中間带が存在し，さらに深部の 外側面には接着斑が存在する.

細胞基底部には強い基底陥入が存在し，その高さ は平均 $7.9 \pm 2.29 \mu \mathrm{m}$ である. 基底陥入の形態は線条 部のそれに比べ，より複雑な形態をとっている。線 条部の管腔は比較的小さいのに比へ排出管の管腔は 大きく，水分やミネラルの代謝に関与するために， 基底陥入がより強くなっているのではないかと考え られる。また線条部は 1 種の細胞から構成されてい るのに比し, 排出管の場合は隣り合う細胞がしばし
ば異種の細胞であることが多く，そのために一層基 底陥入の形態が複雑化するものと考えられる。そし て基底陥入の強い発達に伴なって糸粒体の発達も良 好になっている.その大きさは, 細胞基底部で（2.1 $\pm 0.70) \times(0.6 \pm 0.15) \mu \mathrm{m}$, 先端部付近では $(1.1$ $\pm 0.47) \times(0.7 \pm 0.17) \mu \mathrm{m}$ である.

粗面小胞体の発達は, 排出管の中では, この細胞 が最も良好であった。

分泌果粒の大きいものは認められないが，細胞の 先端部には線条部に存在したような, 直径0.15 $0.30 \mu \mathrm{m}$ の微小な電子密度の高い分泌果粒が認めら れることがある（図13）。

\section{2）暗調円柱細胞}

暗調円柱細胞も排出管を構成する細胞の一つで, 明調円柱細胞に次いで多く存在する。暗調円柱細胞 の形は, 明調円柱細胞と同様に, 細胞のたけの高い 円柱状を呈するが, 細胞の高さ $26.0 \pm 8.06 \mu \mathrm{m}$ に対 し, 細胞の幅7.1 $\pm 2.31 \mu \mathrm{m}$ であり, より幅の狭い形 態をとる.

核の形は，明調細胞のようには平滑ではなく，表 面に山凸のある鵎冠状を呈している。大きさも

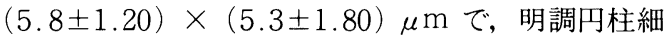
胞より小型である。核の位置は長軸のほぼ $1 / 2$ 程度の ところに位置している。

管腔面細胞膜には, 長さ0.2-0.4 $\mu \mathrm{m}$ の良く発達し た微絨毛の突出が数多く認められる。またそれとは 別に管腔面には，1.5 2.0 $\mu \mathrm{m}$ 程度のアポクリン分 泌様突起が認められる(図13). 従って管腔面の外形 は波状を呈している。隣接細胞境界部の管腔面には $1.0 \mu \mathrm{m}$ 内外の比較的深い溝が存在し, 溝の底部には 良く発達した密着帯が存在している。さらに下方に は, いくつかの接着斑が存在し周囲には細い細系が 認められる。

細胞質の電子密度は比較的高く, 基底線条を有す る部分以外の細胞質全域にわたり多数の小胞が存在 する（図14）。細胞基底部には，明調円柱細胞からの びてくる基底陥入によって，より強い基底線条を呈 し，その長さは基底面より $11.8 \pm 5.89 \mu \mathrm{m}$ である. このよく発達した基底線条と細胞質中の多数の小胞 の存在を考慮すると, 暗調円柱細胞は大量の水分代 謝に関与しているものと考えられる。従って系粒体 の発達は, 極めて良好で, 数も多く大きさは細胞基 底部で $(2.3 \pm 1.64) \times(0.6 \pm 0.09) \mu \mathrm{m}$, 先端部で は $(0.9 \pm 0.34) \times(0.6 \pm 0.14) \mu \mathrm{m}$ であった。粗 
面小胞体の発達も比較的良好である。

3）基底細胞

基底細胞は排出管の中では最も数は少ないが，た けの高い明調円柱細胞または暗調円柱細胞の間で, 管腔から遠く離れ，導管の基底面に密着したような 状態で存在する細胞である (図14). 基底細胞の高さ は, $7.6 \pm 9.05 \mu \mathrm{m}$, 幅は $5.2 \pm 4.40 \mu \mathrm{m}$ である。

核の大きさは $(6.7 \pm 2.85) \times(4.5 \pm 0.92) \mu \mathrm{m}$ で 比較的大きく, 従って細胞全体に対して核の占める 割合は, 極雄大きい。系粒体は, 1 個の細胞断面 に数個存在するのみでその発達も不良で，大きさは (0.5 \pm 0.19$) \times(0.3 \pm 0.03) \mu \mathrm{m}$ に過ぎない。粗 面小胞体の発達は不良である。分泌果粒は全く認め られなかった。

\section{II 正常雄ラット顎下腺}

前項では正常雌ラット顎下腺について述べた。本 項では雌ラット顎下腺に対比して, 正常雄ラット顎 下腺について述べる。

\section{A 介在部 (Intercalated duct)}

1）介在部の形成

雄の介在部導管も雌と同様に, 一方は腺房に結合 し，他方は線条部に結合する導管系の初部である。 介在部の外形も基本的には雌と同じである。介在部 の外径は最小 $12.7 \mu \mathrm{m}$, 最大 $31.4 \mu \mathrm{m}$, 平均 $20.3 \pm$ $8.23 \mu \mathrm{m}$ で内径は最小 $3.5 \mu \mathrm{m}$, 最大 $13.7 \mu \mathrm{m}$, 平均

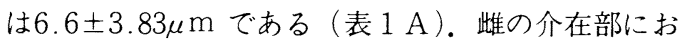
いて見られたように, 介在部細胞と腺房細胞が一つ の管腔を共有する所が認められた。

また基底部付近で介在部細胞が互いに接する部分 には強い指状嵌合がみられる所（図15）と，その発 達が比較的弱いところがある。また介在部細胞と腺 房が基底部付近で接する場合は多くは強い指状嵌合 を認めないが, 一部では強い指状嵌合がみられるこ とがある。

2）細胞の形と核の外形

雄の介在部の細胞基底部の外周は比較的滑らかで ある。介在部の大きさは雌の介在部とほとんど変わ りなく, 細胞の高さは最小 $2.8 \mu \mathrm{m}$, 最大 $16.7 \mu \mathrm{m}$, 平 均 $7.8 \pm 4.36 \mu \mathrm{m}$ 細胞の幅は最小 $3.1 \mu \mathrm{m}$, 最大 19.1 $\mu \mathrm{m}$, 平均 $8.2 \pm 3.91 \mu \mathrm{m}$ で, 若干細胞の幅が高さに 優る. 介在部の内径は最小 $3.5 \mu \mathrm{m}$, 最大 $13.7 \mu \mathrm{m}$, 平 均 $9.1 \pm 4.16 \mu \mathrm{m}$ で, 雌の内径よりも若干大きい.
核は比較的大きく，平均 $(6.2 \pm 3.09) \times(3.9 \pm$ 1.30） $\mu \mathrm{m}$ である。核の位置は細胞の高さのほぼ中 央に位置し, 基底面から, $4.0 \pm 2.88 \mu \mathrm{m}$ である。

3）介在部細胞の先端部

管腔に最も近いところで, 個々の細胞が接する部 分には密着帯がみられる。それよりも基底側で細胞 側壁の細胞の接触面には接着斑が存在する、細胞質 先端部から管腔に向って短い微絨毛の突出がみられ るのも雌と同様である。

4）介在部細胞の分類

介在部を構成する細胞には雌と同様に以下の 3 型 が存在する。
a) 暗調細胞 (dark cell)
b ) 果粒細胞 (granulated cell)
c) 筋上皮細胞 (myoepithelial cell)

a ) 介在部暗調細胞

無果粒性の暗調細胞は雄の介在部で最も頻繁にみ られるものである。暗調細胞と果粒細胞との比率は, おおむね $3 ： 2$ である。

暗調細胞は細胞の大きさが小さく,さらに核が比 較的大きいため細胞質は狭小である。暗調細胞の高 さは最小 $2.8 \mu \mathrm{m}$, 最大 $12.4 \mu \mathrm{m}$, 平均 $6.8 \pm 2.68 \mu \mathrm{m}$ で, 細胞の幅は最小 $3.1 \mu \mathrm{m}$, 最大 $19.0 \mu \mathrm{m}$, 平均 $7.8 \pm$ $4.36 \mu \mathrm{m}$ である.

核の大きさは, 平均 $(3.9 \pm 1.30) \times(6.2 \pm 3.09)$ $\mu \mathrm{m}$ である。細胞質中の糸粒体の発達は貧弱で数は 少ない，系粒体の大きさは，平均 $(0.65 \pm 0.22) \times$

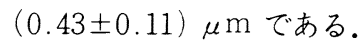

b ) 介在部果粒細胞

分泌果粒を有する果粒細胞は雄の場合も数多く存 在する。しかし個々の果粒細胞は雌のそれに比べ細 胞質の電子密度のきわだって低いものは少なく, 暗 調細胞と同程度のものが多い。また細胞内に含まれ る分泌果粒の数も概して少なく, 少数の分泌果粒を 含む果粒細胞が大部分を占める.

細胞の大きさは, 高さが最小 $3.8 \mu \mathrm{m}$, 最大 $16.7 \mu \mathrm{m}$, 平均 $9.4 \pm 3.48 \mu \mathrm{m}$ で, 細胞の幅は最小 $4.0 \mu \mathrm{m}$, 最大 $14.8 \mu \mathrm{m}$, 平均 $8.7 \mu \mathrm{m}$ である.

核の大きさは, 高さが最小 $3.8 \mu \mathrm{m}$, 最大 $16.7 \mu \mathrm{m}$, 平均 $9.4 \pm 3.48 \mu \mathrm{m}$ で, 細胞の幅は最小 $4.0 \mu \mathrm{m}$, 最大 $14.8 \mu \mathrm{m}$, 平均 $8.7 \mu \mathrm{m}$ である.

核の大きさは，管腔から基底面に垂直な方向に $4.7 \pm 2.3 \mu \mathrm{m}$, 基底面に平行な方向に $5.5 \pm 2.2 \mu \mathrm{m}$ である。 
糸粒体の発達は貧弱で, その大きさは, 長軸が最 小 $0.4 \mu \mathrm{m}$, 最大 $2.1 \mu \mathrm{m}$, 平均 $1.0 \pm 0.45 \mu \mathrm{m}$ で, 短軸 は最小 $0.3 \mu \mathrm{m}$, 最大 $0.6 \mu \mathrm{m}$, 平均 $0.5 \pm 0.10 \mu \mathrm{m}$ であ る. 細胞小器官の発達は概して不良であるが, 一部 には粗面小胞体の良く発達している細胞が認められ た。

雄の果粒細胞の分泌果粒は雌と同様に比較的小型 で電子密度の高いものが大部分を占めただ 1 種類の 分泌果粒と思われる(図15)。しかし果粒細胞に含ま れる分必果粒の数は䧳に比べて明らかに少ない，1 細胞断面に現れる分泌果粒の数は, 平均8.9 55.19 個 である. 分泌果粒の大きさは, 最小 $0.2 \mu \mathrm{m}$, 最大 $1.0 \mu \mathrm{m}$, 平均 $0.6 \pm 0.15 \mu \mathrm{m}$ である. 分泌果粒の大き さには，著明な性差は認められなかった。

C) 筋上皮細胞

雄の介在部にみられる筋上皮細胞も雌のそれと異 なる所は少なく, 細胞の長軸を介在部の基底面に平 行に向けている．筋上皮細胞の細胞質の電子密度は 暗調細胞より若干低い。細胞質内には多数の筋細系 が存在し, その走向は細胞長軸に一致している. 細 胞小器官の発達は不良である。

\section{B 線状部 (Striated duct)}

1) 線条部の形状

雄の線条部は雌の線条部と同様に, 導管系のほぼ 中央に存し, 初部は介在部から続き, 終部は排出管 へ連続する、線条部と果粒性膨大部との比率は, 雌 の場合では線条部の方が優位であったのに比べ, 雄 の場合は果粒性膨大部の方が圧倒的に優位であり, 純粋な形での線条部は極めて僅かしか見られない。 線条部の横断像は円形から棈円形である。外径は, $27.4 \pm 11.9 \mu \mathrm{m}$ である. 雌の線条部も導管全体の大 きさに比べ内径が小さかったが, さらに雄の線条部 は小さく, $2.8 \pm 3.0 \mu \mathrm{m}$ に過ぎない。また雌の線条 部と同様に, 細胞基底面より管腔に向ってほぼ垂直 に基底線条が走っている．基底線条の走向に沿って 極めて良く発達した長桿状の系粒体がみられる。

細胞の大きさは, 高さが最小 $6.6 \mu \mathrm{m}$, 最大 $20.6 \mu \mathrm{m}$, 平均 $13.4 \pm 4.05 \mu \mathrm{m}$ で, 細胞の幅は最小 $4.5 \mu \mathrm{m}$, 最 大 $19.1 \mu \mathrm{m}$, 平均 $9.5 \pm 3.9 \mu \mathrm{m}$ である. 細胞の大き さについては, 雌雄差はほとんど認められなかった (表 1 B).

\section{2) 細胞の核}

核の位置は,ほぼ細胞長軸の中心で基底面より 6.1 $\pm 2.1 \mu \mathrm{m}$ の位置にある.核の大きさは最小 $2.5 \times 2.0$ $\mu \mathrm{m}$, 最大 $5.4 \times 6.0 \mu \mathrm{m}$, 平均は $(4.9 \pm 1.4) \times(4.8$ 土1.6) $\mu \mathrm{m}$ である。核の外形は球形または楕円形 を呈する。核の外周は比較的滑らかで，核内にはへ テロクロマチン様構造がみられる。核小体は明瞭で 電子密度は高く,その大きさは $(0.84 \pm 0.16) \times(0.69$ $\pm 0.16) \mu \mathrm{m}$ である。細胞質の電子密度は, 一般に 低く, 雌にみられた電子密度の高い暗調細胞は認め られない。

3）細胞の先端部

細胞先端部には，長さ0.5 1.0 $\mu \mathrm{m}$ の微絨毛が認 められる。微絨毛は果粒を含む細胞では数は少なく, 長さも短いが, 無果粒細胞では微絨毛は長い傾向に ある(図16)。管腔面の ballooning 現象は認められな い.

雌の線条部では管腔に面する細胞のほとんどすべ てに, 電子密度の高い小型暗調果粒が認められたが, 雄では一部の細胞の先端部に分泌果粒が認められる のみで, 多くの細胞は無果粒である．雄の細胞先端 部に含まれる分泌果粒は雌と同じく，小型の暗調果 粒と, 明調果粒の 2 種類が存在する. 分泌果粒の計 測には, 果粒性膨大部に含まれる線条部細胞を加之 た.小型暗調果粒は 1 細胞断面に $29.6 \pm 11.77$ 個存在 し, 直径は $0.2 \pm 0.06 \mu \mathrm{m}$ である. 明調果粒は $22.3 \pm$ 4.64 個で, 直径は $0.7 \pm 0.08 \mu \mathrm{m}$ である。無果粒細胞 の先端部には分必果粒よりははるかに小さな, 直径 $94 \pm 20.3 \mathrm{~nm}$ の小胞が集まっていることがある（図 16).

\section{4）細胞の基底部}

細胞基底部には良く発達した基底線条のみられる 細胞（図17）と，それ程顕著な発達を示さない細胞 とが存在する.良く発達した基底線条の長さは $3.9 \pm$ $0.09 \mu \mathrm{m}$ 細胞の高さに対し基底部からおよそ $1 / 3$ 程 の位置であり, 基底線条の良く発達した細胞でも, 雌の基底線条に比べると，その発達は若干劣るよう である。

\section{5）系粒体}

雄の系粒体の発達も導管系の中では線条部が最も 高度である。また雌の場合と同様に細胞基底部と先 端部とでは，その発達に差異があり，基底部の方が 系粒体の大きさと数が優っている。系粒体の直径は, 基底部では $(1.5 \pm 0.08) \times(0.5 \pm 0.13) \mu \mathrm{m}$ であ $\eta$, 先端部では $(0.58 \pm 0.03) \times(0.41 \pm 0.03) \mu \mathrm{m}$ である。系粒体の大きさは細胞基底部, 先端部とも 
に雌に比べ明らかに雄の方が小さい.

\section{C 果粒性膨大部 (Granular duct)}

1）果粒性膨大部の形状

果粒性膨大部の外形は雌と同様, 横断面で円形な いし棈円形を呈するが，その大きさは雌より若干大 きく, 最小 $40.1 \mu \mathrm{m}$, 最大 $77.1 \mu \mathrm{m}$, 平均 $56.8 \pm 13.00$ $\mu \mathrm{m}$ である.内径は最小 $4.5 \mu \mathrm{m}$, 最大 $15.0 \mu \mathrm{m}$, 平均 $10.2 \pm 3.88 \mu \mathrm{m}$ であり, 導管壁の厚さは, 最小 19.5 $\mu \mathrm{m}$, 最大 $30.9 \mu \mathrm{m}$, 平均は $24.4 \pm 4.41 \mu \mathrm{m}$ である.

(表 1 C)

果粒性膨大部の個々の細胞分類は，雌の場合と同 様に以下の 5 種に分類することが出来る.

I 型 基底細胞 (dark cell)

II 型 暗調狭細胞 (dark narrow cell)

III 型 明調狭細胞 (light narrow cell)

IV 型 明調果粒細胞 (light granular cell)

V型 暗調果粒細胞 (dark granular cell)

以上 5 型細胞の出現頻度を雌の場合に比べると, 基底細胞の出現頻度は雌10.0\%に比べ雄13.6\%とほ とんど変らず，暗調狭細胞と明調狭細胞が雌では， いずれも $16.0 \%$ であったものが,雄ではそれぞれ 4.9 および $.5 \%$ と極端に少なく，これに対して，暗調果 粒細胞が雌では34.0\%であったものが, 雄では $54.3 \%$ と極端に多い。明調果粒細胞は䧳 $24.0 \%$, 雄 $24.7 \%$ と変らない (表 2 )。これを要するに, 狭細胞が雌に 多く, 暗調果粒細胞が雄に極端に多い事実は, 狭細 胞が多量の果粒を有するようになると果粒細胞に変 わることが出来，雌に比べて雄では果粒性膨大部の 果粒が著明に増加していると解することができる.

2）基底細胞

基底細胞は腺上皮の基底部に偏して存在し管腔に 面しないため, 細胞の高さは比較的低く, 最小 3.3 $\mu \mathrm{m}$, 最大 $22.1 \mu \mathrm{m}$, 平均 $10.8 \pm 4.92 \mu \mathrm{m}$ である。細 胞の幅は比較的広く, 最小 $14.5 \mu \mathrm{m}$, 最大 $36.9 \mu \mathrm{m}$, 平均 $17.6 \pm 7.68 \mu \mathrm{m}$ である。雌に比べると細胞の高 さは有意の差はなく, 細胞の幅は雄の方が優ってい る。

核の直径は, $(5.4 \pm 2.19) \times(6.2 \pm 1.99) \mu \mathrm{m}$ で, 僅かに雄の方が優り，ほぼ球形に近い楕円形を号し ている，核の外周には圧迫傾向はみられず比較的滑 らかである。細胞質の電子密度は比較的高い。系粒 体は細胞質全域にわたり存在するが，その大きさは 小さく, $(1.3 \pm 0.45) \times(0.54 \pm 0.18) \mu \mathrm{m}$ であり
系粒体の大きさには雌雄差は認められなかった。粗 面小胞体の発達は比較的良好であり, 時に核の周囲 には良く発達している。

3）暗調狭細胞

雄の暗調狭細胞は雌に比べると, その出現頻度は 少なく, 全細胞に対して $4.9 \%$ である.細胞の高さは, 最小 $11.0 \mu \mathrm{m}$, 最大 $23.1 \mu \mathrm{m}$, 平均 $18.5 \pm 5.00 \mu \mathrm{m}$ で ある. 細胞の幅は, 最小 $3.1 \mu \mathrm{m}$, 最大 $10.5 \mu \mathrm{m}$, 平均 $6.7 \pm 7.17 \mu \mathrm{m}$ である. 雌に比べると, 細胞の高さは 若干高く, 細胞の幅は狭い.

核は（5.8 $\pm 0.83 ） \times(4.8 \pm 0.47) \mu \mathrm{m}$ でほぼ球 形に近い楕円形を呈する。核の位置は細胞質の中央 よりやや基底側に位置している。細胞質には遊離り ボゾームが多数存在し電子密度は比較的高い。細胞

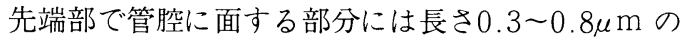
微絨毛が突出している(図18)。系粒体は細胞質全域 に広く分布しているが, 数は少なく, 大きさも小さ いものが大部分である. 基底部付近の糸粒体は最小 $0.5 \times 0.4 \mu \mathrm{m}$, 最大 $3.2 \times 0.8 \mu \mathrm{m}$ 平均 $(1.6 \pm 0.83) \times$ $(0.6 \pm 0.40) \mu \mathrm{m}$, 先端部では最小 $0.6 \times 0.2 \mu \mathrm{m}$, 最 大 $1.9 \times 0.6 \mu \mathrm{m}$, 平均 $(0.9 \pm 0.40) \times(0.5 \pm 0.13)$ $\mu \mathrm{m}$, である. 系粒体の大きさには著明な雌雄差は認 められなかった。

雄の暗調狭細胞の大部分は分泌果粒を含まない。 特に雌にしばしばみられた電子密度の高い小暗調果 粒は, いずれの細胞にも存在しなかった。ごく一部 の細胞に直径 $0.3 \pm 0.02 \mu \mathrm{m}$ の小さい電子密度の低 い空胞状の果粒が認められるに過ぎない。粗面小胞 体の発達は貧弱であり，基底細胞と比べてもさらに 劣る。

4）明調狭細胞

雌の明調狭細胞の発現頻度が16.0\%であるのに比 し, 雄の明調狭細胞は数少なく, 僅かに $2.5 \%$ 占め るに過ぎない.明調狭細胞の高さは, $14.9 \pm 4.17 \mu \mathrm{m}$, 幅は5.1 $1.07 \mu \mathrm{m}$ で雌に比し幅がより狭くなって いる.

核は楕円形を呈し，核上部の圧迫傾向は認められ ない。核の大きさは, 平均 $4.4 \times 3.0 \mu \mathrm{m}$ で, 核の位 置は基底部からおよそ $4.8 \mu \mathrm{m}$ の位置で, 細胞の中心 より若干基底部よりに位置している。

系粒体の発達は良好で, 細胞先端部の分泌果粒を 含む部分を除いては，核上部，核側部，および核下 部から基底部にかけて球形から楕円形の系粒体が認 められる。系粒体の大きさは基底部では, (1.67土 
$0.84) \times(0.37 \pm 0.07) \mu \mathrm{m}$ で長桿状を呈し, 先端部 では $(0.46 \pm 0.02) \times(0.42 \pm 0.01) \mu \mathrm{m}$ で，ほぼ 球形を呈している. 系粒体の直径は, 雌に比べると, 基底部では若干大きく, 先端部ではやや小さい.

雌の明調狭細胞の一部には, 電子密度の高い大暗 調果粒が認められたが, 雄の場合には, この大暗調 果粒は全く認められない。明調果粒と小暗調果粒は, 一部の細胞先端部に認められた (図19)。分泌果粒の 直径は, 明調果粒が $0.8 \pm 0.18 \mu \mathrm{m}$, 暗調果粒は $0.2 \pm$ $0.01 \mu \mathrm{m}$ で，この 2 種の分泌果粒の大きさに関する かぎり, 明らかな雌雄差は認められない。しかし大 暗調果粒が雄に認められないので, 雄の明調狭細胞 の分泌果粒は全体として小型であるという印象が強 い. 粗面小胞体の発達は中等度であり, 特に核上部 に発達している(図19).

5) 明調果粒細胞

明調果粒細胞の発現頻度は，雌が $24.0 \%$ あるるの に比し, 雄は24.7\%であり, ほとんど性差は認めら れない, 明調果粒細胞の高さは, 最小 $9.1 \mu \mathrm{m}$, 最大 $15.5 \mu \mathrm{m}$, 平均 $17.8 \pm 6.60 \mu \mathrm{m}$ で, 幅は最小 $4.3 \mu \mathrm{m}$, 最大 $15.5 \mu \mathrm{m}$, 平均 $10.2 \pm 3.60 \mu \mathrm{m}$ である. 雌に比 し, 細胞の高さは, ほとんど同じで幅は雌より狭く なっている。

核は球形から楕円形を呈し，一部の核には，分泌 果粒の蓄積による核上縁の圧迫傾向がみられる（図 $20)$. 核の大きさは $(5.7 \pm 1.83) \times(5.5 \pm 2.19) \mu \mathrm{m}$ で, 雌よりやや小型である。核の位置は, 基底面か ら平均 $4.7 \pm 1.09 \mu \mathrm{m}$ で, これは細胞の高さに対し, およそ下位 $1 / 4$ の位置を占め, 雌に比べて基底側に偏 位している。

糸粒体の発達は良好であるが, 先端部には分泌果 粒が蓄積しているため糸粒体は主として核側部と核 下部に存在している，糸粒体には長桿状のものは少 なく, 球形から棈円形を呈している。系粒体の大き さは, 基底部で $(1.3 \pm 0.62) \times(0.6 \pm 0.23) \mu \mathrm{m}$, 先 端部で $(0.8 \pm 0.35) \times(0.5 \pm 0.19) \mu \mathrm{m}$ である. 雌 に比べると，基底部ではほとんど同じであり，先端 部では有意に雌より短かかった。

分泌果粒は雌同様, 外形不正で電子密度が低い明 調果粒が多く存在し, それに少数の大暗調果粒が混 在し，小暗調果粒も若干含まれている。また明調果 粒の一部には, 融合が認められることがある．分泌 果粒の 1 細胞断面の個数は, 明調果粒が $29.5 \pm 8.11$ 個で,小暗調果粒は $19.2 \pm 17.58$ 個, 大暗調果粒は 8.8
土12.29個である．雌に比べると，いずれの分必果 粒も有意に多く含まれている。分泌果粒の平均直径 は, 明調果粒が $2.0 \pm 0.54 \mu \mathrm{m}$, 小暗調果粒は $0.3 \pm$ $0.07 \mu \mathrm{m}$, 大暗調果粒は $1.7 \pm 0.85 \mu \mathrm{m}$ である.雌との 比較では，小暗調果粒には有意の差は認められない が，明調果粒と大暗調果粒は有意に大きかった。

管腔面より突出する微絨毛の発達は不良であり, 細胞によっては, 微絨毛を欠く場合があり, 微䋐毛 を有する場合でも，その長さは $0.3 \sim 0.5 \mu \mathrm{m}$ 程であ る. 粗面小胞体の発達は果粒管細胞の中では最も高 度で特に細胞基底部に良く発達しているものが認め られる。

6 ) 暗調果粒細胞

暗調果粒細胞の出現頻度は $54.3 \%$ で, 全細胞の過 半数を占め, 雌の $34 \%$ に比べて有意に明調果粒細胞 の占める比率が高い. 細胞の高さは, 最小 $7.9 \mu \mathrm{m}$, 最大 $31.9 \mu \mathrm{m}$, 平均 $17.1 \pm 6.32 \mu \mathrm{m}$ で，幅は最小 5.1 $\mu \mathrm{m}$, 最大 $28.6 \mu \mathrm{m}$, 平均 $12.4 \pm 6.40 \mu \mathrm{m}$ である. 細 胞の大きさに関するかぎり，高さも幅も共に有意の 性差は認められなかった。

核の位置は, 基底面から $3.7 \pm 1.93 \mu \mathrm{m}$ で, 細胞の 高さに対して，ほぼ下位 $1 / 5 \sim 1 / 4$ の位置を占めてい て, 核の位置にも有意の雌雄差は認められない。核 の大きさは $(3.7 \pm 1.93) \times(4.4 \pm 1.68) \mu \mathrm{m}$ であ り，雌の核とほとんど変わりがなかった，分泌果粒 の蓄積による核上縁の陥凹も認められた（図21）。

糸粒体の発達は比較的良好であるが, 暗調果粒細 胞の細胞質の大部分は分泌果粒で満たされているた め, 良く発達した系粒体は細胞基底部に存在する。 系粒体の大きさは，基底部で $(1.0 \pm 0.45) \times(0.5 \pm$ $0.18) \mu \mathrm{m}$ で, 先端部では $(0.9 \pm 0.46) \times(0.5 \pm$ 0.19) $\mu \mathrm{m}$ で, 特に雌雄差は認められない。粗面小 胞体の発達は良好であるが, 主として核下部に良く 発達している(図21).

分泌果粒には雌と同様に, 明調果粒, 小暗調果粒, および大暗調果粒の 3 種が存在する。細胞 1 断面に 含まれる分泌果粒の数は, 明調果粒が $2.7 \pm 0.47$ 個, 小暗調果粒は $28.7 \pm 16.29$ 個, 大暗調果粒は $34.9 \pm$ 14.32個である。雌と比べると, 明調果粒には有意の 差はなく, 小暗調果粒はかなり多く, 大暗調果粒は 有意に多い. 分泌果粒の大きさは, 明調果粒が $1.7 \pm$ $0.22 \mu \mathrm{m}$, 小暗調果粒は $0.4 \pm 0.05 \mu \mathrm{m}$, 大暗調果粒は $2.1 \pm 0.51 \mu \mathrm{m}$ である. 雌に比べ, 明調果粒と小暗調 果粒は若干大きく大暗調果粒は，かなり大きい. 
以上の結果は暗調果粒細胞の数（出現頻度）が雌 に比べて雄において約1.6倍と極めて高いと同時に， 個々の細胞内の果粒数が多く, かつ大暗調果粒が大 きさも数もともに雄は雌の約1.5倍に増加している から, 雌に比べて極めて大量の分泌物を保有するこ とが明らかである。

果粒性膨大部の各細胞区分を度外視して, 切片上 に出現する暗調果粒と明調果粒の占める面積を計測 し, それぞれの果粒の面積が, 果粒性膨大部の細胞 の面積に対する百分比を求めると, 正常雄ラットで は暗調果粒が $35.45 \pm 18.57 \%$, 明調果粒は $14.84 \pm$ $11.14 \%$, 総果粒面積は $50.29 \pm 14.15 \%$ であるのに対 して，正常雌ラットではそれぞれ，21.72 $\pm 8.35 \%$, $11.47 \pm 8.98 \% ， 33.26 \pm 9.78 \%$ となる。暗調果粒と 明調果粒の面積（体積）比は雄で2.39, 雌で1.89と なる。すなわち暗調果粒は明調果粒に比して, 雄雌 ともに, 約 2 倍の量を示める. 総果粒量は雄ラット が雌ラットに比して面積\%で約1.5倍, 果粒性膨大部 の管壁の厚さの雌雄差を考慮した補正值において は, 雄が雌の約1.86倍多く果粒を含むことが明らか となった（表 3 ).

表 3 ラット顎下腺果粒性膨大部の果粒量比

A 各果粒の面積百分比

平均土標準偏差

\begin{tabular}{c|c|c|c}
\hline & 正常 雄 & 去勢 雄 & 正常 雌 \\
\hline 暗 調 果 粒 & $35.45 \pm 18.57$ & $46.24 \pm 14.36$ & $21.72 \pm 8.35$ \\
\hline 明 調 果 粒 & $14.84 \pm 11.14$ & $6.71 \pm 7.56$ & $11.47 \pm 8.98$ \\
\hline 総 果 粒 量 & $50.29 \pm 14.15$ & $52.95 \pm 11.26$ & $33.26 \pm 9.78$ \\
\hline
\end{tabular}

B 各果粒量の管壁厚による補正比

\begin{tabular}{l|r|r|r}
\hline & 正 常 雄 & 去勢 雄 & 正 常 雌 \\
\hline 暗調果粒 & 863.20 & 1171.07 & 429.62 \\
\hline 明調果粒 & 361.35 & 154.53 & 226.87 \\
\hline 総果粒量 & 1224.56 & 1219.43 & 657.88 \\
\hline
\end{tabular}

\section{D 排出管 (Excretory duct)}

排出管は導管系の最終部であるから，その大きさ は他の部分に比べて大きい. 排出管の大きさは, 外 径 $50.1 \mu \mathrm{m}$, 内径 $10.7 \mu \mathrm{m}$, 導管の厚さ $21.0 \pm 1.38 \mu \mathrm{m}$ である。しかし，大型の排出管を管腔を含めて一視 野にとらえることが困難な場合が多く，その大きさ について，雌雄差を検討するには致らなかった。ま
た雄の排出管も雌と同様に，3 種類の細胞型すなわ ち, 明調円柱細胞, 暗調円柱細胞，および，基底細 胞から構成されている。

1）明調円柱細胞

明調円柱細胞は雄の場合も排出管の中で, 最も多 く存在する細胞型である。細胞の高さは24.9 77.98 $\mu \mathrm{m}$, 幅は $14.9 \pm 5.07 \mu \mathrm{m}$ で, 雌に比し, 僅かに幅が 優っている.

核の大きさは $(7.4 \pm 1.56) \times(7.0 \pm 1.85) \mu \mathrm{m}$ で, ほほ球形を呈し, 雌に比べ有意の差は認められな かった。

核の位置は基底面よりおよそ3/5に位置し,管腔面 にやや近い位置にある。核の位置は，雌の場合とほ ぼ同様である。

管腔に面している細胞膜には，短い微絨毛の突出 が認められ，時としてアポクリン様突起も認められ る (図22). 細胞質の電子密度は低く, 雌と変らない. 細胞先端部の管腔面に近い部分で，隣接する細胞と 接触する所には密着帯がみられ，さらに深部の外側 面には，いくつかの接着斑が認められる。細胞基底 部には, 排出管の特徵である強い基底陥入が存在し, その高さは7.6 $1.78 \mu \mathrm{m}$ で, 䧳とほとんど同じであ る。

系粒体の発達は良好であるが, 細胞基底部と先端 部では, 発達の程度に差異があり, 基底部の方に, 良く発達した糸粒体が認められる。系粒体の大きさ は, 基底部で $(2.5 \pm 0.83) \times(0.7 \pm 0.15) \mu \mathrm{m}$, 先 端部では $(1.1 \pm 0.31) \times(0.5 \pm 0.10) \mu \mathrm{m}$ である. 糸粒体の大きさには，ほとんど雌雄差は認められな い. 断面小胞体とゴルジ装置の発達は良好であり， 特に核上部では良く発達している。

分泌果粒は細胞先端部から, 基底部一向って3.9土 $0.60 \mu \mathrm{m}$ の限られた範囲に存在し, 電子密度は高く, 球形を呈し, 1 細胞断面に $30.0 \pm 7.94$ 個存在し, 直 径は $0.26 \pm 0.12 \mu \mathrm{m}$ である. 分泌果粒の個数および 大きさには，きわだった雌雄差は認められない。

\section{2）暗調円柱細胞}

暗調円柱細胞は, 明調円柱細胞に次いで多く存在 する.暗調円柱細胞の大きさは, 細胞の高さが19.6士 $2.32 \mu \mathrm{m}$ で, 細胞の幅は8.6 $1.89 \mu \mathrm{m}$ である. 雌に 比べると細胞の高さは僅かに低く, 細胞の幅には変 異がない.

核の外形は，やや不正で表面に凹凸がみられる。 核の大きさは $(6.7 \pm 1.64) \times(4.5 \pm 0.28) \mu \mathrm{m}$ で 
ある。核の位置は長軸のほぼ $1 / 2$ 程度の所にある。核 の外形，核の大きさ，および核の位置には，特に性 差は認められない。管腔面細胞膜には, 長さ0.2 $0.4 \mu \mathrm{m}$ の微絨毛の突出が認められる。管腔面の外形 は中央部がやや膨隆し, 逆に隣接細胞境界部の管腔 面には, $1.0 \mu \mathrm{m}$ 内外の樑い溝が存在する. 溝の底部 には密着帯が存在し，それよりも深い所には中間帯 があり，その下方の外側面には，いくつかの密着斑 が存在する.

細胞質の電子密度は比較的高い，基底線条を有す る部分を除く細胞質全域に多数の不正形の小空胞が 存在する.この小空胞の大きさは $0.8 \pm 0.22 \mu \mathrm{m}$ であ る. 細胞基底部の基底線条は, $7.6 \pm 0.98 \mu \mathrm{m}$ で雌に 比べ明らかに短い，系粒体の発達は良好であり，基 底部で $(1.9 \pm 0.59) \times(0.8 \pm 0.19) \mu \mathrm{m}$, 先端部で $(1.1 \pm 0.33) \times(0.6 \pm 0.12) \mu \mathrm{m}$ である。粗面小 胞体の発達は不良で, 明調円柱細胞より劣る。

\section{3）基底細胞}

基底細胞は管腔に面せず，導管基底側に偏位して 存在し, 数は少ない. 基底細胞の大きさは, 高さ8. $9 \pm 2.40 \mu \mathrm{m}$, 細胞の幅 $8.2 \pm 3.34 \mu \mathrm{m}$ である. 細胞の 大きさは，僅かであるが雄の方が雌より大きい．核 の大きさは, $(4.0 \pm 0.99) \times(2.6 \pm 0.54) \mu \mathrm{m}$ で, 雌より僅かに小さい。

細胞質の電子密度は比較的高く, 暗調円柱細胞と 同程度であり，雌雄差も認められない。系粒体の発 達は良好ではなく，1 細胞断面に数個存在するに過

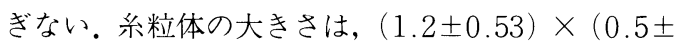
0.11） $\mu \mathrm{m}$ で，雄より若干大きい。粗面小胞体の発 達は不良である。分泌果粒も雌同様存在しない。

\section{III去勢ラット顎下腺}

前項までに，正常雄ラットと正常雌ラットの顎下 腺における所見を記載した。本項では雄の去勢後 4 か月のラット顎下腺について，述べる.

\section{A 介在部 (Intercalated duct)}

1）介在部の形状

去勢雄ラットの介在部導管の外形は正常雄と変わ る所はない. 導管の外径は $21.2 \pm 6.58 \mu \mathrm{m}$, 導管の内 径は, $5.4 \pm 3.42 \mu \mathrm{m}$, 導管壁の厚さ $8.5 \pm 2.52 \mu \mathrm{m}$ で あり，正常雄とほとんど差はなかった（表 $1 \mathrm{~A}$ )。正 常此雄にみられた介在部細胞と腺房細胞が同一の管 腔を共有する所見は去勢雄でも見られる(図23). 基
底部付近で隣接する部分には，強い指状嵌合が認め られる。

2）細胞の形と核の外形

去勢雄の介在部細胞の大きさは, 細胞の高さ $7.1 \pm$ $3.14 \mu \mathrm{m}$ で, 細胞の幅は7.5 $53.46 \mu \mathrm{m}$ である。細胞 の大きさは正常雄とほぼ同等である。核は正常雄に 比し若干小さく, $(3.6 \pm 1.55) \times(6.1 \pm 2.16) \mu \mathrm{m}$ である，核の位置は細胞の高さに対し，やや基底部 寄りに位置し, 基底面より $2.5 \pm 1.26 \mu \mathrm{m}$ の位置にあ る。

3）介在部細胞の先端部

隣接する細胞が管腔側で接する所には, 密着帯が みられ, さらに下方の細胞外側面には, 複数の接着 斑が存在する (図23)。細胞質先端部から管腔に向っ て短い微絨毛の突出がみられる。微絨毛の形態も正 常雄と差異は認められない。

4）介在部細胞の分類

介在部を構成する細胞には正常此雄と同様に，以 下の 3 型が存在する.

a) 暗調細胞 (dark cell)

b ) 果粒細胞 (granulated cell)

c ) 筋上皮細胞 (myoepithelial cell)

a ) 介在部暗調細胞

分泌果粒を含まない暗調細胞は, 去勢雄の介在部 の大部分を占めるものであり, 正常雌雄に比しその 出現率は著しく大きい。暗調細胞と明調果粒細胞と の比率は，おおむね20：1であった。暗調細胞の高 さは最小 $1.7 \mu \mathrm{m}$, 最大 $12.4 \mu \mathrm{m}$, 平均 $7.1 \pm 3.14 \mu \mathrm{m}$ で, 細胞の幅は最小 $2.3 \mu \mathrm{m}$, 最大 $13.0 \mu \mathrm{m}$, 平均 $7.4 \pm$ $3.09 \mu \mathrm{m}$ である。核の大きさは $(3.6 \pm 1.57) \times(6$. 1士2.20) $\mu \mathrm{m}$ である. 細胞の大きさ，および核の大 きさは正常雄と有意の差がなかった。細胞質の電子 密度は比較的高く, 系粒体の発達は貧弱で, その数 は少ない.糸粒体の大きさは $(0.8 \pm 0.35) \times(0.4 \pm$ 0.15） $\mu \mathrm{m}$ である.

b ) 介在部果粒細胞

分泌果粒を有する果粒細胞は，去勢雄の場合は極 端に少ない。細胞質の電子密度は明調細胞より低い。 分泌果粒は少ない，果粒細胞 1 断面に数個含まれる に過ぎない。

細胞の大きさは, 高さが最小 $5.5 \mu \mathrm{m}$, 最大 $7.7 \mu \mathrm{m}$, 平均 $6.6 \pm 0.92 \mu \mathrm{m}$ で, 細胞の幅は最小 $3.9 \mu \mathrm{m}$, 最大 $21.2 \mu \mathrm{m}$, 平均 $10.2 \pm 7.82 \mu \mathrm{m}$ である. 細胞の大きさ は, 正常雄に比し, 細胞の高さは若干低く, 細胞の 
幅は広い，核の大きさは $(3.6 \pm 1.01) \times(6.4 \pm 1$. 22） $\mu \mathrm{m}$ であり，正常雄に比し有意の差はなかった。 核の位置は基底面より，2.6 $00.78 \mu \mathrm{m}$ で，僅かに基 底部寄りに位置している。

系粒体の発達は貧弱で，大きさは $(0.7 \pm 0.33) \times$ (0.4 0.04$) \mu \mathrm{m}$ で, 正常雄より小型で, むしろ正 常雌と同程度である。粗面小胞体の発達は不良であ る.

分泌果粒は小型で, 電子密度は高く, 去勢雄の場 合も，ただ 1 種類の分泌果粒である。しかし，果粒 細胞に含まれる分泌果粒の数は極めて少なく，1 細 胞断面に現われる分泌果粒の数は, $2.0 \pm 1.00$ 個であ る. 分泌果粒の大きさは最小 $0.5 \mu \mathrm{m}$, 最大 $0.7 \mu \mathrm{m}$, 平均 $0.6 \pm 0.05 \mu \mathrm{m}$ である.分泌果粒の数は正常此雄 に比べ少なく，果粒の大きさは，正常雄と差異は無 かった。

C ) 筋上皮細胞

去勢雄の介在部に付着する筋上皮細胞は，細胞の 長軸を介在部の基底面に平行に向けている。時には 長い突起が介在部導管を包んでいる場合がある（図 24).筋上皮細胞の高さは $4.9 \pm 1.55 \mu \mathrm{m}$, 細胞の幅は $18.1 \pm 6.46 \mu \mathrm{m}$ で幅の広い形態を呈する。核の位置 は基底面から $2.4 \pm 0.59 \mu \mathrm{m}$ で, 細胞の高さのほぼ中 央に位置している。核の大きさは $(3.5 \pm 0.61) \times(9$. $0 \pm 3.22) \mu \mathrm{m}$ で横に広くなっている.核および細胞 質の電子密度は暗調細胞より有意に低い。細胞質内 には，細胞長軸に一致した方向に筋細系が存在する が著明ではない。

糸粒体の発達は貧弱であるが, 暗調細胞よりは良 好で，良く発達した系粒体も観察される。系粒体の 大きさは $(1.2 \pm 0.68) \times(0.5 \pm 0.16) \mu \mathrm{m}$ である.

\section{B 線条部 (Striated duct)}

1) 線条部の形状

線条部と果粒性膨大部との比率は，雌の場合は線 条部が優位であり，雄の場合は逆に果粒性膨大部が 圧倒的に多い。去勢雄では，果粒性膨大部の方が正 常雄と同様に優位を占めており，純粋な形での線条 部は少なかった。去勢雄の線条部細胞の一部には分 泌果粒を含むものがある。

線条部の横断像は, 円形あるいは, 楕円形を呈す る。線条部の大きさは, 外径 $39.8 \pm 9.28 \mu \mathrm{m}$ である (表 1 B ). 線条部の大きさは正常雄より優り, 雌に 近似している．また，細胞基底面より管腔に向って
強い基底線条が認められる，その走向に沿って良く 発達した糸粒体が数多く存在する (図25). 細胞の大 きさは, 高さが最小 $6.8 \mu \mathrm{m}$, 最大 $18.5 \mu \mathrm{m}$, 平均 12 . $8 \pm 0.30 \mu \mathrm{m}$ で, 細胞の幅は最小 $5.4 \mu \mathrm{m}$, 最大 21.9 $\mu \mathrm{m}$, 平均 $13.5 \pm 0.60 \mu \mathrm{m}$ である. 細胞の大きさは, 雌に良く似ている。

2）細胞の核

核の位置は, ほぼ細胞長軸の中心で, 基底面より

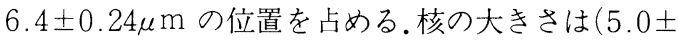

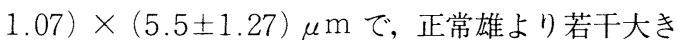
い。核の外形は球形または楕円形を呈する。核の外 周は比較的滑らかである。核小体の直径は測定出来 たものでは, $1.3 \times 1.3 \mu \mathrm{m}$ であった。

3） 細胞の先端部

細胞の先端部には, ごく短い微絨毛の突出がみら れる。また，細胞先端部には小型の暗調果粒と明調 果粒が存在する，分必果粒の計測は，純粋な線条部 細胞に加え，果粒性膨大部に含まれる線条部細胞の 計測を行なった。小型の暗調果粒は 1 細胞断面に $31.0 \pm 23.71$ 個存在し, 直径は $0.28 \pm 0.08 \mu \mathrm{m}$ であ る。明調果粒は 1 細胞断面に $17.3 \pm 5.79$ 個存在し, 直径は $0.43 \pm 0.10 \mu \mathrm{m}$ である. 正常雌雄と比較する と, 小型の暗調果粒の個数, 直径ともに正常雄に似 ている。明調果粒の個数抒よび直径は, 正常雌雄の 中間に值する。

4）細胞の基底部

細胞基底部には良く発達した基底線条を有する細 胞（図25）と発達の悪い細胞とが存在する. 発達の 良い基底線条は $7.0 \pm 0.41 \mu \mathrm{m}$ で，細胞の高さに対 し基底部からおよそ1/2に達する，去勢雄の基底線 条は，正常雄より有意に良く発達し，雌に良く近似 している。

5）糸粒体

糸粒体の発達は正常雌雄と同様に, 導管系の中で は線条部が最も高度である。しかし, 系粒体の発達 は細胞基底部と先端部とでは, 細胞基底部の方が 優っている.系粒体の大きさは細胞基底部で (1.7士 $0.17) \times(0.85 \pm 0.18) \mu \mathrm{m}$ で, 先端部は $(1.0 \pm 0.17)$ $\times(0.6 \pm 0.11) \mu \mathrm{m}$ である. 糸粒体の大きさは，基 底部，先端部ともに正常雄より有意に大きく雌に近 似している。

C 果粒性膨大部 (Granular duct) 去勢雄の果粒性膨大部は，正常雄に準じて良く発 
達している。しかし果粒性膨大部の個々の細胞につ いては, 正常雄とは異なる結果が得られた。

1）果粒性膨大部は比較的大形で，その断面は円 形ないし楕円形を呈する.導管の外径は最小 $34.6 \mu \mathrm{m}$, 最大 $65.7 \mu \mathrm{m}$, 平均 $50.9 \pm 9.00 \mu \mathrm{m}$ で, 内径は最小 $1.9 \mu \mathrm{m}$, 最大 $15.2 \mu \mathrm{m}$, 平均 $8.4 \pm 4.10 \mu \mathrm{m}$ である. 導管壁の厚さは最小 $17.6 \mu \mathrm{m}$,最大 $32.2 \mu \mathrm{m}$, 平均 23.0 $\pm 3.79 \mu \mathrm{m}$ である (表 $1 \mathrm{C}$ ). 導管の外径, 内径と も，正常雌より大きく，正常雄よりは小さく，ほぼ 雌と雄の中間の大きさである.

果粒性膨大部の細胞分類は, 正常雌雄と同様に以 下の 5 種が出現する.

I 型 基底細胞 (basal cell)

II 型 暗調狭細胞 (dark narrow cell)

III型 明調狭細胞 (light narrow cell)

V 型 明調果粒細胞 (light granular cell)

V 型 暗調果粒細胞 (dark granular cell)

去勢雄ラットにおける果粒性膨大部の各型細胞の 出現頻度を正常雄と比較すると, 暗調果粒細胞の出 現率が極端に増加して，その他の細胞型の出現頻度 がすべて減少していることは，去勢によって雌の状 態に近似しているのではなく, 増々暗調果粒細胞と いう雄の特徵を有する細胞が増加しているという奇 妙な結果になっている(表 2 ). しかしこの場合に極 端に減少している細胞は明調果粒細胞であるから，

果粒の電子密度に変化を生じた結果に過ぎないと考 えることも出来る.

2）基底細胞

基底細胞は腺上皮の基底部に偏して存在するた め, 細胞の高さは低く, 細胞の幅は広い。細胞の高 さは最小 $4.3 \mu \mathrm{m}$, 最大 $8.8 \mu \mathrm{m}$, 平均 $6.0 \pm 1.51 \mu \mathrm{m}$, 細胞の幅は最小 $11.7 \mu \mathrm{m}$, 最大 $19.5 \mu \mathrm{m}$, 平均 $15.8 \pm$ $2.77 \mu \mathrm{m}$ である. 正常雄に比べると, 細胞の高さは 低く, 細胞の幅には有意の差はない。

核の形は球形から腺上皮の基底面に平行な方向に 長い楕円形を呈している。核の大きさは（3.5 $1.26) \times(5.5 \pm 0.76) \mu \mathrm{m}$ で, 正常雄より僅かに小さ い(図26).

細胞質の電子密度は正常雌雄と同程度で比較的高 い. 系粒体の発達は, 明調果粒細胞および暗調果粒 細胞よりは良好で細胞質全域にわたり存在する。系 粒体の大きさは比較的小さく $(1.1 \pm 0.40) \times(0.38 \pm$ 0.09） $\mu \mathrm{m}$ である。系粒体の大きさには正常雌雄と 有意の差は無い。粗面小胞体は核の周囲に良く観察
される。

\section{3）暗調狭細胞}

去勢雄では, 暗調狭細胞の出現頻度は少なく, 全 細胞に対して $2.1 \%$ あ゙る。細胞の高さは最小 13.8 $\mu \mathrm{m}$, 最大 $21.6 \mu \mathrm{m}$, 平均 $18.5 \pm 3.34 \mu \mathrm{m}$ で, 細胞の 幅は最小 $4.2 \mu \mathrm{m}$, 最大 $5.2 \mu \mathrm{m}$, 平均 $4.6 \pm 0.46 \mu \mathrm{m}$ で ある. 正常雄に比し, 細胞の高さは一致し, 細胞の 幅は僅かに狭い。

核は球形に近い楕円形を呈する，核の位置は細胞 長軸に対して下位 $1 / 3$ に位置している．細胞質の電 子密度は比較的高い. 細胞先端部で管腔に面する部 分には, 長さ $0.2 \sim 0.6 \mu \mathrm{m}$ の微絨毛が突出している (困27, 29).

糸粒体の発達は, 良好で細胞質全域に存在するが, 長桿状を呈するものは少なく, その多くは球形に近 い楕円形である，糸粒体の大きさは，基底部付近で $(1.3 \pm 0.65) \times(0.58 \pm 0.13) \mu \mathrm{m}$, 先端部では $(0.8$ $\pm 0.42) \times(0.4 \pm 0.08) \mu \mathrm{m}$ である. 系粒体の大 きさは正常雄に比し, ごく僅か小さいのみで, ほと んど同程度である。

去勢雄の分泌果粒には, 正常雌と同様, 小さい暗 調果粒と明調果粒の 2 種が出現した。暗調果粒は 1 細胞断面に 10.5 個存在し, 大きさは $0.16 \pm 0.02 \mu \mathrm{m}$ である。明調果粒は 1 細胞断面に 23 個存在し, 大き さは正常雄よりさらに小さく $0.18 \pm 0.03 \mu \mathrm{m}$ であ る。粗面小胞体の発達は貧弱である。

4）明調狭細胞

去勢雄では, 明調狭細胞の出現頻度は非常に少な く，28\%であり，正常雄に一致する。明調狭細胞の 高さは最小 $13.2 \mu \mathrm{m}$, 最大 $23.1 \mu \mathrm{m}$, 平均 $19.2 \pm 4.08$ $\mu \mathrm{m}$ で, 細胞の幅は最小 $3.3 \mu \mathrm{m}$, 最大 $19.1 \mu \mathrm{m}$, 平均 $10.2 \pm 6.25 \mu \mathrm{m}$ である. 正常雌および雄と比べると, 細胞の高さは正常雌および雄より若干優り, 細胞の 幅は雌に一致する。

核は球形に近い棈円形を呈し，核小体は比較的 明瞭である。核の大きさは $(9.0 \pm 0.92) \times(7.9 \pm$ 3.40） $\mu \mathrm{m}$ である。核の位置は細胞長軸のほぼ中央 である。

細胞質の電子密度は低い, 糸粒体の発達は良好で あり，ほぼ細胞質全域にわたり存在する。おそらく 全細胞型の中で最も良好と思われる。糸粒体の発達 は，細胞基底部と先端部とでは若干異なり，細胞基 底部の方が優る。糸粒体の大きさは, 細胞基底部で $(1.7 \pm 0.68) \times(0.6 \pm 0.15) \mu \mathrm{m}$, 先端部では $(1.0$ 
$\pm 0.20) \times(0.6 \pm 0.17) \mu \mathrm{m}$ である. 系粒体の大 きさは, 正常雌および雄と比べると, 細胞基底部は 正常雄に一致し, 細胞先端部では, 正常雌にほぼ一 致する。

明調狭細胞には，暗調果粒と明調果粒の 2 種が存 在する (図28)。また，正常雄同様に大暗調果粒は認 められなかった。暗調果粒は 1 細胞断面に $18.7 \pm$ 8.37 個存在し, 直径は $0.25 \pm 0.04 \mu \mathrm{m}$ である。明調 果粒は 1 細胞断面に 26 個も存在する例があり，直径 は0.64 $00.20 \mu \mathrm{m}$ である。正常雌および雄と比べる と, 分泌果粒の個数は, 暗調果粒, 明調果粒ともに 多く, 分泌果粒の直径は暗調果粒が正常此と雄の中 間の值で，明調果粒は正常雄よりさらに僅かに小さ い. 粗面小胞体の発達は比較的良好で, 特に核上部 で良く発達している。

5）明調果粒細胞

去勢雄の明調果粒細胞の出現頻度は, 正常雌およ び雄に比し，極端に少なく，8.5\%である。明調果粒 細胞の高さは最小 $9.1 \mu \mathrm{m}$, 最大 $25.5 \mu \mathrm{m}$, 平均 17.2 $\pm 4.50 \mu \mathrm{m}$ で，細胞の幅は最小 $3.3 \mu \mathrm{m}$, 最大 12.9 $\mu \mathrm{m}$, 平均 $8.2 \pm 3.32 \mu \mathrm{m}$ である。細胞の高さは, 正 常雄にほぼ一致し, 細胞の幅は, それより若干狭い。

核は比較的大きく，球形から楕円形を呈する。核 の電子密度は比較的低い(図29). 核の大きさは(5.7 $\pm 1.61) \times(4.8 \pm 1.73) \mu \mathrm{m}$ であり, 正常雄と比 較して差異は無い.核の位置は基底面より $6.5 \pm 1.51$ $\mu \mathrm{m}$ で, 細胞長軸のおよそ下位 $1 / 3$ に位置し, 正常雄 より高い位置にあり雌にほぼ一致する。

糸粒体の発達は良好であるが, 主として核側部と 基底部に存在する．特に基底部では，良く発達した 長桿状の糸粒体が認められる。糸粒体の大きさは基 底部で $(1.5 \pm 0.93) \times(0.6 \pm 0.16) \mu \mathrm{m}$ である. 正 常雄に比べると基底部でごく僅か長いが，ほとんど 同程度である。

分泌果粒には，正常雌および雄同様，明調果粒を 主とし，それに比較的数の多い小暗調果粒，および 一部には大暗調果粒の 3 種が含まれる(図29). 分泌 果粒の 1 細胞断面に含まれる個数は, 明調果粒が $26.0 \pm 8.54$ 個, 小暗調果粒は10.8 23.26 個, 大暗調果 粒は2.0土0.81個である. 正常雌および雄と比べる と, 明調果粒と小暗調果粒は正常雌と雄のほぼ中間 である。大暗調果粒は正常雌雄のいずれよりも少 ない, 分泌果粒の平均直径は, 明調果粒が0.9 0 0.27 $\mu \mathrm{m}$, 小暗調果粒は $0.3 \pm 0.05 \mu \mathrm{m}$, 大暗調果粒は, 0.7 $\pm 0.02 \mu \mathrm{m}$ である. 明調果粒の直径は, 雌に比べ僅 かに小さく,さらに正常雄に比べると著しく小さく, その約 $1 / 2$ に過ぎない.小暗調果粒には正常雌および 雄と有意の差は認められない。大暗調果粒も正常雄 と比べ有意に小さい.

管腔面より突出する微絨毛の発達は, 貧弱であり, その長さは0.2 0.6 $\mu \mathrm{m}$ 程である. 粗面小胞体の発 達は良好で，特に核上部と基底部で高度である。

6) 暗調果粒細胞

暗調果粒細胞の出現頻度は $80.9 \%$ と極めて高く, 正常雄に比しても有意に高い。細胞の高さは，最小 $5.4 \mu \mathrm{m}$, 最大 $26.7 \mu \mathrm{m}$, 平均 $16.0 \pm 5.28 \mu \mathrm{m}$ で, 細胞 の幅は最小 $2.7 \mu \mathrm{m}$, 最大 $38.8 \mu \mathrm{m}$, 平均 $12.5 \pm 5.79$ $\mu \mathrm{m}$ である。細胞の大きさについては, 高さも幅も 正常雄にほぼ一致している。

核は基底面に平行な方向に長い楕円形を呈し，核 小体は比較的明瞭である。核の位置は基底面から $3.8 \pm 1.95 \mu \mathrm{m}$ で, 細胞長軸に対しておよそ下位 $1 / 5$ 〜1/4の位置を占め，核の位置も正常雄に，ほぼ一 致する.核の大きさは $(4.2 \pm 1.47) \times(5.62 \pm 1.95)$ $\mu \mathrm{m}$ で，ほとんど正常雄に一致している. 分泌果粒 の蓄積による核上縁の陥凹も多くの細胞に認められ る.

糸粒体の発達は, 正常雌掞よび雄同様, 細胞基底 部で良好である。系粒体の大きさは, 細胞基底部で $(1.1 \pm 0.57) \times(0.5 \pm 0.14) \mu \mathrm{m}$, 先端部で $(0.8 \pm$ $0.33) \times(0.5 \pm 0.14) \mu \mathrm{m}$ である。系粒体の大きさ は正常雄に一致する。粗面小胞体の発達は良好であ り，主として核側部と核下部に良く発達している。 分泌果粒には, 正常雌雄と同様, 明調果粒, 小暗調 果粒，および主な分泌果粒である大暗調果粒の 3 種 が存在する. 1 細胞断面に含まれる分泌果粒の数は,

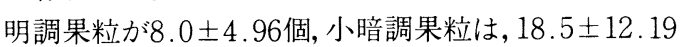
個, 大暗調果粒は $38.9 \pm 21.23$ 個である. 正常雌およ び雄と比較すると, 明調果粒は正常雌および雄より 有意に多く，小暗調果粒は正常雌および雄のほぼ中 間の数で, 大喑調果粒は正常雄とほぼ同数である.分 泌果粒の大きさは, 明調果粒が, $1.6 \pm 0.20 \mu \mathrm{m}$, 小 暗調果粒は $0.3 \pm 0.07 \mu \mathrm{m} ， 大$ 暗調果粒は $1.3 \pm 0.28$ $\mu \mathrm{m}$ である。正常雌および雄と比較すると, 明調果 粒は正常雄とほとんど同じで，小暗調果粒は正常雌 雄の中間で, 大暗調果粒は正常雄より有意に小さく, 雌にほぼ一致する。

ラット顎下腺の性差を最も顕著にあらわす果粒性 
膨大部の暗調果粒細胞の数は去勢によって，むしろ 増加しているが，その中に含まれる大暗調果粒は去 勢によって減少はしないが，個々の果粒の大きさは 著明に減少している。

果粒性膨大部の明・暗 2 種の果粒細胞に出現する 分泌果粒は共通して, 明調果粒，小暗調果粒および 大暗調果粒の 3 種であり，この中，小暗調果粒は去 勢によって大きさの変化をほとんど起さない，明調 果粒と大暗調果粒はいずれも去勢によって著しくそ の大きさを減ずる。しかし暗調果粒細胞では上記両 果粒とも去勢によって著明に増数する。しかも暗調 果粒細胞の出現率が去勢によって増加するので，明 調果粒と大暗調果粒の量が去勢によってどのように 変化したかを比べるには, 両者の果粒の断面積を計 測して比較する必要が生ずる。面積\%で比較すると， 暗調果調（大，小果粒を合せて）は正常雄で35.45土 $18.57 \%$ が去勢雄では $46.24 \pm 14.36 \%$ と増加し, 明調 果粒は $14.84 \pm 11.14 \%$ から $6.71 \pm 7.56 \%$ と減少して いる.この傾向は果粒性膨大部の管壁の厚さによっ て補正しても変らない。しかし総果粒量の補正值は 正常雄と去勢雄の間にほとんど差はなく，去勢雄で 僅かに減少しているが有意ではない。そして暗調果 粒が増加し, 明調果粒が減少していることは前述の 通りである(表 3 ). したがって去勢の影響は端的に 言えば, 明調果粒の中の約半分が暗調果粒に変った と考えればよい。しかし，これは去勢のために暗調 果粒から明調果粒への変化が抑之られたと解するこ ともできる。このことによって去勢の結果, 暗調果 粒細胞の数が, 極端に増加する（表 2 ）事実も説明 することができる。

\section{D 排出管 (Excretory duct)}

排出管の外径は $82.7 \pm 4.48 \mu \mathrm{m}$, 内径 $30.6 \pm 6.92$ $\mu \mathrm{m}$, 導管の厚さ $27.7 \pm 5.75 \mu \mathrm{m}$ である.また, 去勢 雄の排出管も正常雌雄と同様に明調円柱細胞, 暗調 円柱細胞, および基底細胞の 3 型を有する。 3 種類 の細胞の発現頻度は明調円柱細胞と暗調円柱細胞が ほぼ同数で，基底細胞は最少である。

\section{1）明調円柱細胞}

明調円柱細胞の高さ25.4 $25.69 \mu \mathrm{m}$, 幅 $13.3 \pm$ $4.15 \mu \mathrm{m}$ で, 正常雄にほぼ一致する。核の大きさは

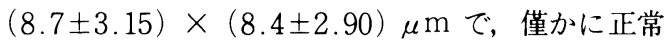
雄より大きい。核は球形に近く，核の位置は細胞基 底面からおよそ $1 / 2$ 位置である。
管腔に面している細胞膜には $0.50 \pm 0.15 \mu \mathrm{m} の$ 微絨毛の突出が認められる。細胞先端部の管腔面に 近い部分で隣接する細胞との間には密着帯がみら れ，さらに梁部の外側面にはいくつかの接着斑が認 められる。細胞基底部の基底陥入は長い部分で10.1 $\pm 2.21 \mu \mathrm{m}$ である。

系粒体の発達は良好であり, 大きさは基底部で $(2.3 \pm 1.07) \times(0.8 \pm 0.21) \mu \mathrm{m}$, 先端部は (1.5土 $0.37) \times(0.8 \pm 0.14) \mu \mathrm{m}$ である. 系粒体の発達に 関しては, 正常雌雄と差異はなかった。粗面小胞体 とゴルジ野の発達は比較的良好であり，特に核上部 では著明である（図30）。

分泌果粒の存在する範囲は細胞先端部より $3.4 \pm$ $0.79 \mu \mathrm{m}$ に限局している。分泌果粒の電子密度は高 く, 形は球形を呈している。分泌果粒は 1 細胞断面 に $35.2 \pm 17.87$ 個存在し，直径は $0.34 \pm 0.22 \mu \mathrm{m}$ で あった．分泌果粒の形態は正常此雄とほとんど同様 である。

2）暗調円柱細胞

暗調円柱細胞の大きさは, 細胞の高さ $27.4 \pm 7.39$ $\mu \mathrm{m}$, 幅13.2 $25.02 \mu \mathrm{m}$ で, 細胞の高さは正常雌に一 致し，幅は雌より広い。核の外形は不正で，電子密 度は明調円柱細胞よりも高い。核の大きさは $(8.7 \pm$ $2.98) \times(7.5 \pm 3.05) \mu \mathrm{m}$ で正常雌雄より大きい. 核の位置は基底部からおよそ3/5の位置である。管腔 面細胞膜には, 長さ $0.8 \pm 0.28 \mu \mathrm{m}$ の比較的長い微絨 毛の突出が認められる。また，隣接細胞境界部の管 腔面には, 深い溝がみられ, 特に深い部分では $5 \mu \mathrm{m}$ 程に達する。細胞質の電子密度は正常雌雄と同様に 比較的高く, 細胞質中に存在する小空胞の大きさは, $0.8 \pm 0.23 \mu \mathrm{m}$ で正常雌雄と差異は無い（図31）。細 胞基底部の基底線条は $13.8 \pm 3.40 \mu \mathrm{m}$ で, 正常雄よ り長く, 正常雌にほぼ一致する (図32)。系粒体の発 達は良好で, 基底部では $(3.0 \pm 0.85)(0.8 \pm 0.20)$ $\mu \mathrm{m}$, 先端部では $(1.6 \pm 0.50) \times(0.8 \pm 0.14) \mu \mathrm{m}$ である(図32）。

\section{3）基底細胞}

基底細胞の大きさは, 高さ $8.8 \pm 3.10 \mu \mathrm{m}$, 幅 $9.0 \pm$ $5.71 \mu \mathrm{m}$ である。細胞の大きさは正常雄にほぼ一致 した。核の大きさは $(6.5 \pm 2.70) \times(2.6 \pm 0.54)$ $\mu \mathrm{m}$ で, 細胞全体に対して大きい部分を占めてい る.

糸粒体の発達は正常雌雄と同様に不良で，大きさ は $(1.1 \pm 0.51) \times(0.6 \pm 0.13) \mu \mathrm{m}$ である。分泌 

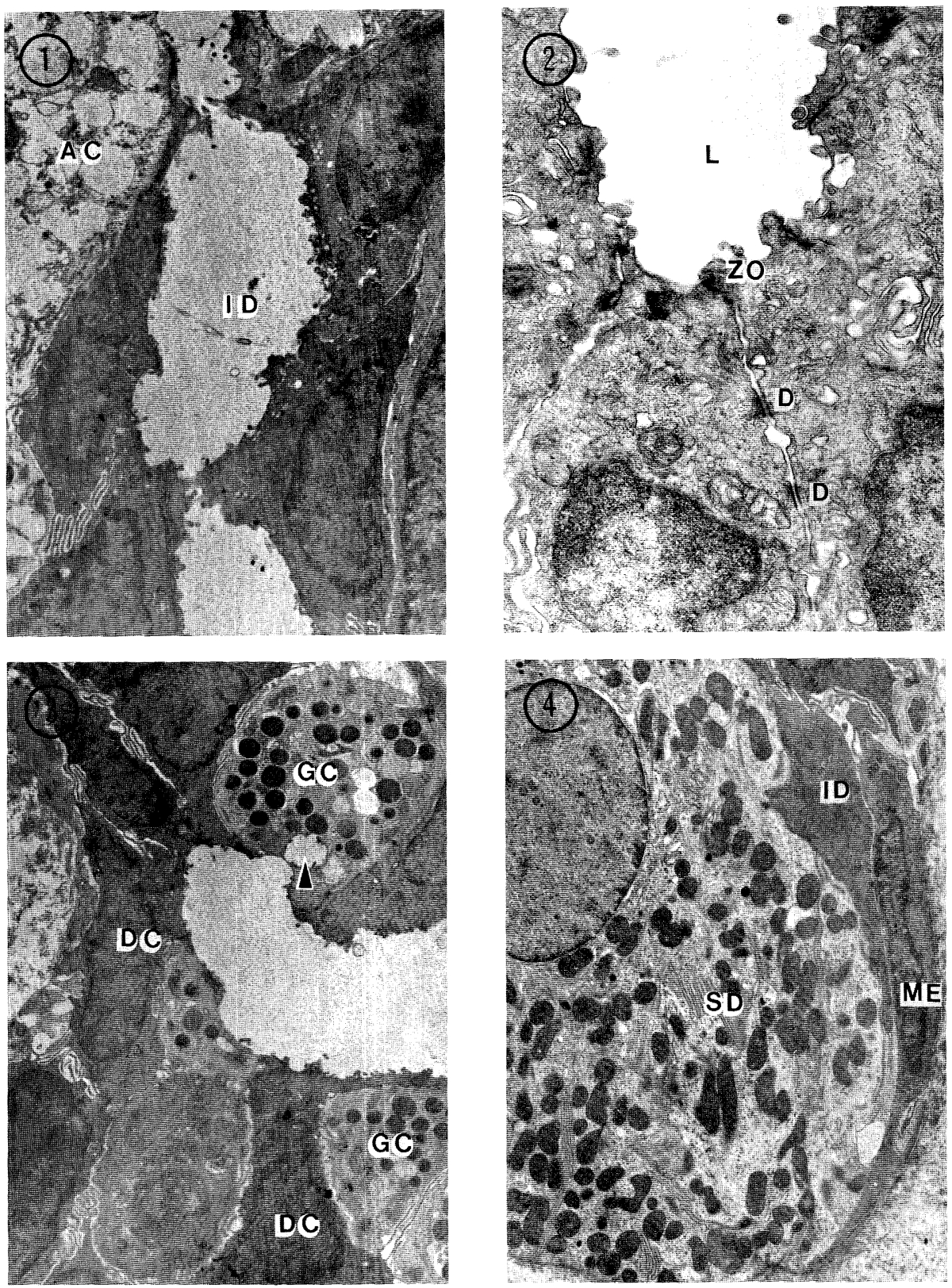

図 1 正常雌ラット顎下腺の介在部（ID）と隣接する腺房細胞 $(\mathrm{AC}) . \times 4000$

図 2 正常雌ラット顎下腺介在部細胞の先端部。管腔 ( L ) に近い細胞接触面に密着帯 $(Z O)$ が見られ， これより深部に数個の接着斑（D）が点在する。 × 12000

図 3 正常此ラッ卜顎下腺介在部。喑調細胞 (DC) と果粒細胞 (GC) の 2 型刃゙混在している。矢印は果 粒細胞の細胞内分泌細管. $\times 4400$

図 4 正常雌ラット顎下腺。介在部 (ID) から線条部 (SD) の外表面へ伸びる筋上皮細胞 (ME). ×4800 

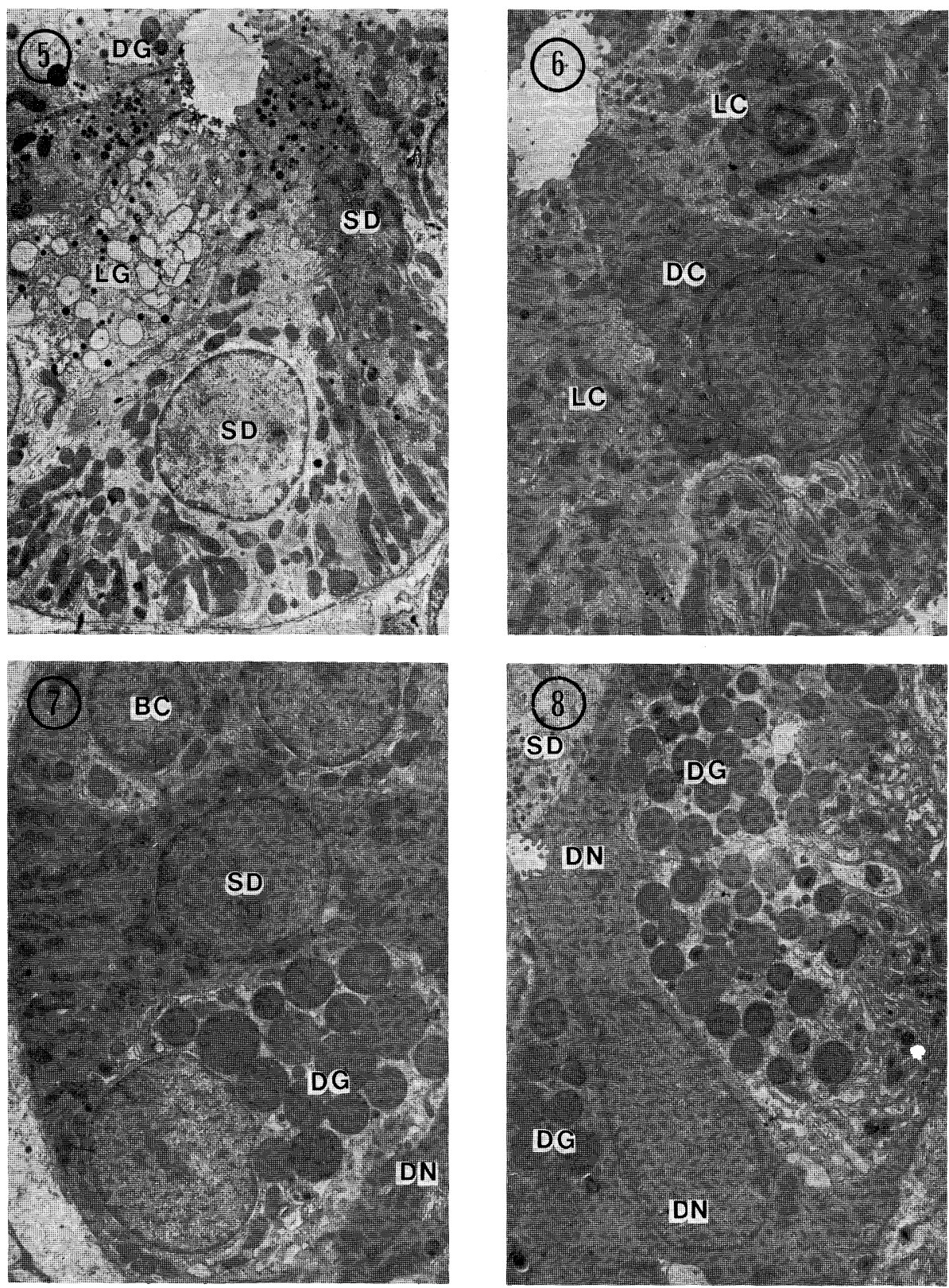

図 5 正常雌ラット顎下腺線条部。線条部細胞 (SD) と果粒性膨大部の明調果粒細胞 (LG) および暗調 果粒細胞 (DG) が混在している。 $\times 2400$

図 6 正常雌ラット顎下腺線条部. 線条部細胞に明調細胞 (LC) と暗調細胞 (DC)の 2 種を区別できる.X 4400

図 7 正常雌ラット顎下腺果粒性膨大部. 基底細胞 (BC), 暗調果粒細胞 (DG), 暗調狭細胞 (DN) の 他に，線条部細胞（SD）の混入を見る。 $\times 4800$

図 8 正常雌ラット顎下腺果粒性膨大部. 典型的な暗調狭細胞 (DN), 暗調果粒細胞 (DG) の他に線条 部細胞 $(S D)$ の先端部が観察できる. $\times 4800$ 

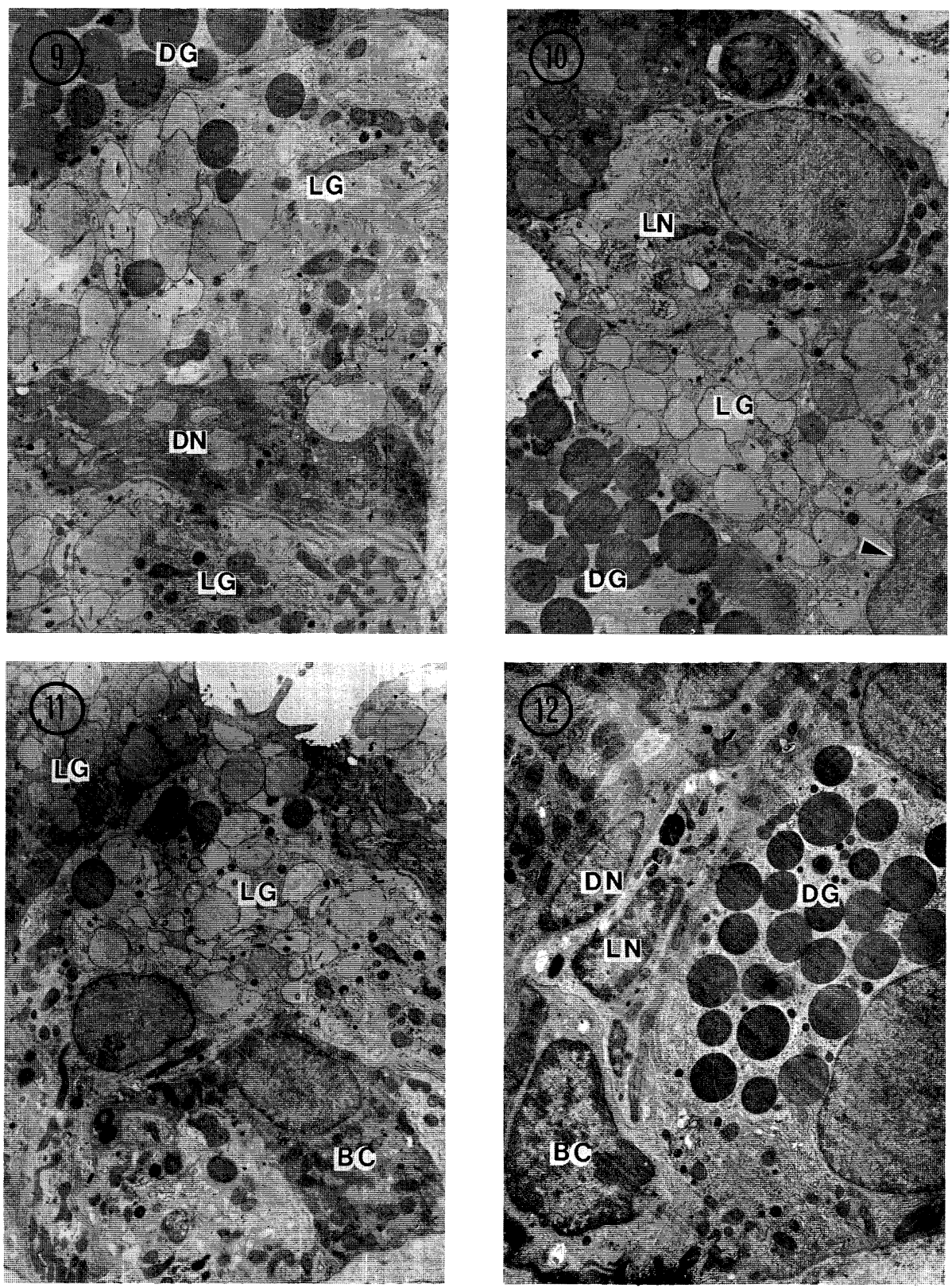

図 9 正常雌ラット顎下腺果粒性膨大部. 少数の分泌果粒を有する暗調狭細胞（DN）の他に典型的な暗 調果粒細胞 (DG) と明調果粒細胞 (LG) が見られる。 × 3200

図10 正常雌ラット顎下腺果粒性膨大部。明調狭細胞 (LN), 明調果粒細胞 (LG) および暗調果粒細胞 (DG)が観察される.矢印は明調果粒細胞の核が分泌果粒によって圧痕を生じたところを示す。 2800

図11 正常雌ラット顎下腺果粒性膨大部。やや暗い基底細胞 (BC) と多くの明調果粒細胞 (LG) が観察 できる。 × 2800

図12正常雌ラット顎下腺果粒性膨大部. 暗調果粒細胞 (DG)の他に, 基底細胞 (BC), 明調狭細胞 (LN), 暗調狭細胞 $(\mathrm{DN})$ 等が見える. $\times 2800$ 

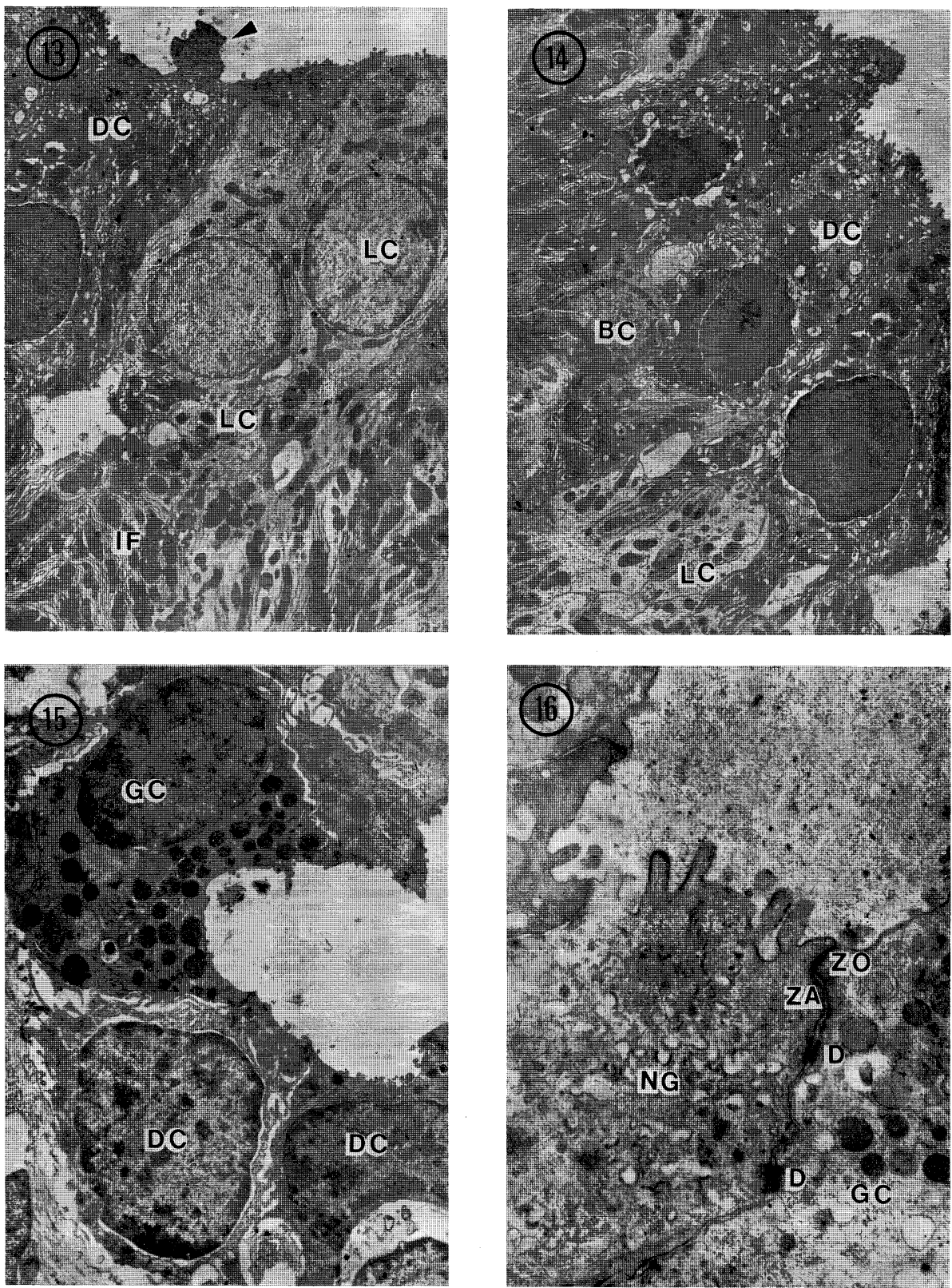

図13 正常雌ラット顎下腺排出管上皮。明調円柱細胞 (LC) と暗調円柱細胞 (DC) が存在し，いずれも 著明な基底陥入（IF）を有し，核が管腔面に近い位置にある。暗調円柱細胞は管腔面にアポクリ ン様突起（矢印）を出している、×2400

図14 正常雌ラット顎下腺排出管上皮. 管腔側には多数の暗調円柱細胞 (DC) が並び，基底側に基底細 胞 $(\mathrm{BC})$ と明調円柱細胞 (LC) の一部が見之る. $\times 2800$

図15 正常雄ラット顎下腺介在部。果粒を含まない暗調細胞 (DC) と，果粒を含む果粒細胞 (GC) が認 められる，後者の細胞質は雌の場合よりも電子密度が高い。 $\times 4000$

図16 正常雄ラット顎下腺線条部細胞の先端部. 無果粒細胞 (NG) と果粒細胞 (GC) が隣接しており, 前者の微絾毛の方が癹達がよい。細胞接触面に密着帯 $(Z O)$, 中問带 $(Z A)$, 接着斑 $(D)$ がこの 順に並んでいる。×13000 

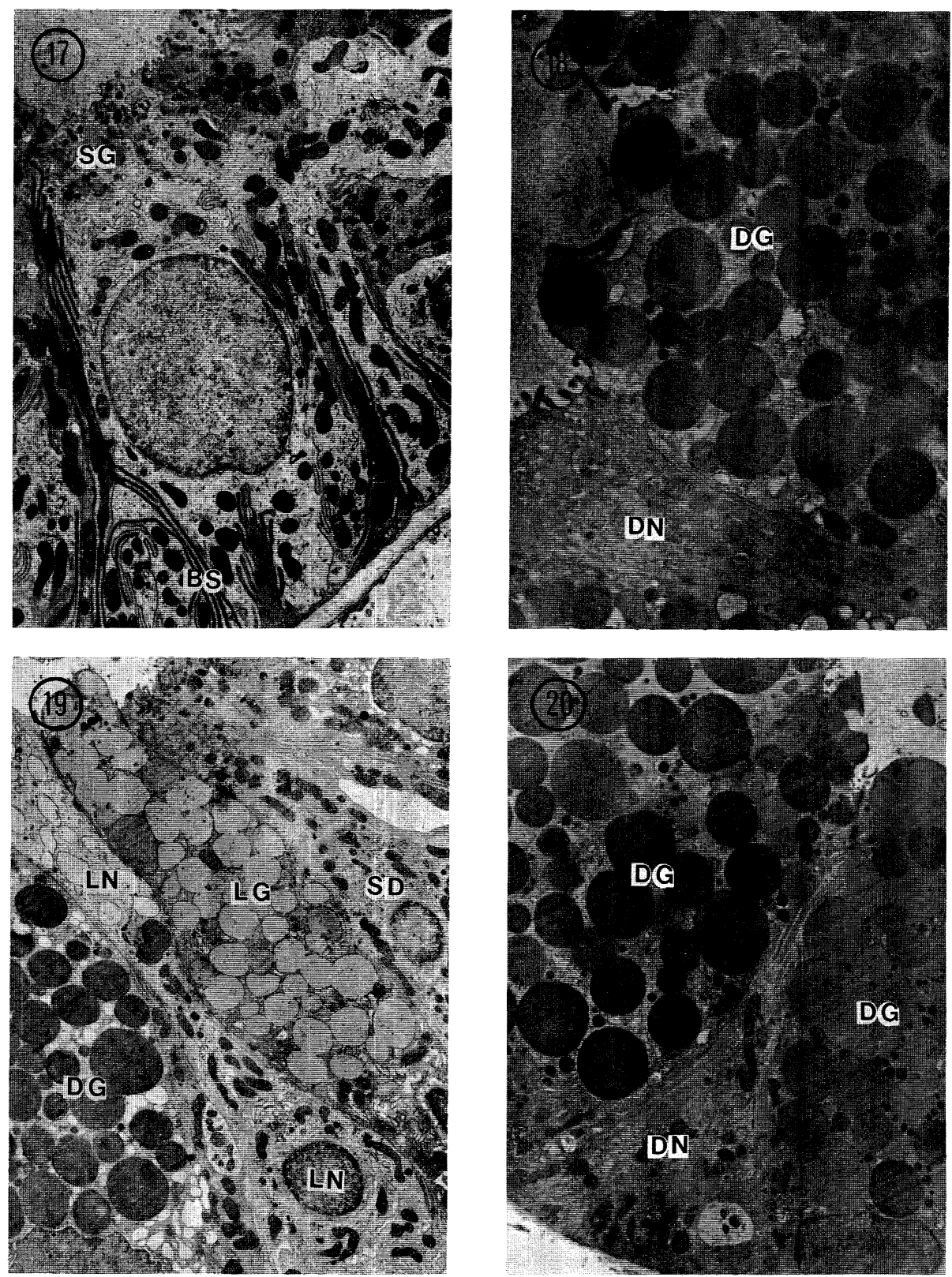

図17 正常雄ラット顎下腺線条部。細胞先端部には少数の分泌果粒（SG）が集積し，基底部には基底線 条 (BS) が存在する．基底線条は大部分隣接する細胞との嵌合によって形成される。×3200

図18 正常雄ラット顎下腺果粒性膨大部の管腔側. 暗調狭細胞 (DN) は微絨毛を多く有するが, 暗調果 粒細胞（DG）には少ない。×4000

図19 正常雄ラット顎下腺果粒性膨大部。暗調果粒細胞 (DG)，明調果粒細胞（LG）および明調狭細胞 (LN) が存在する。 $\times 2400$

図20 正常雄ラット顎下腺果粒性膨大部. 暗調果粒細胞 (DG) と暗調狭細胞 (DN) が見られる. 前者の 分泌果粒のあるものは電子密度中等度で，明調果粒との移行型のように思われる。×4000 

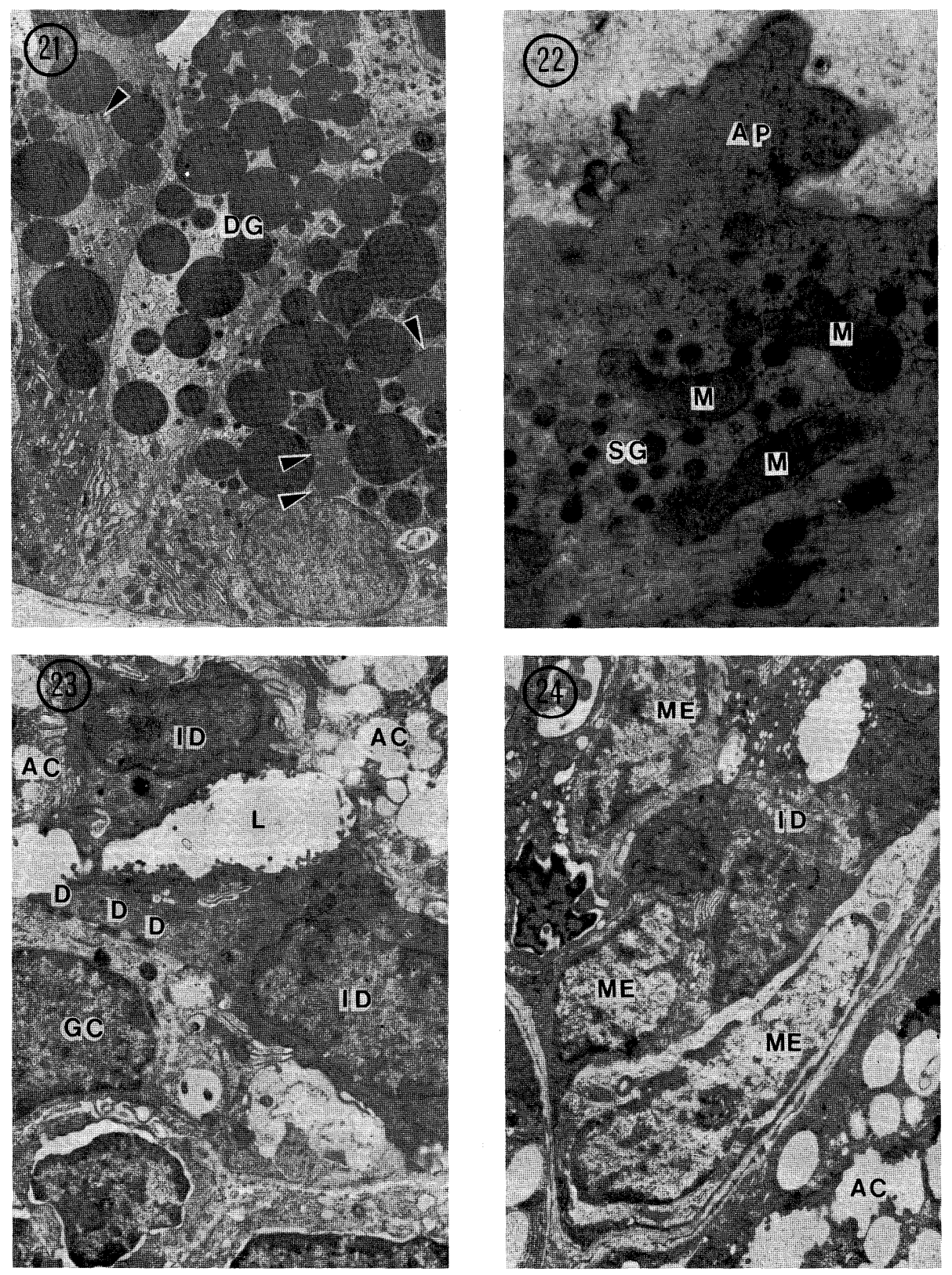

図21 正常雄ラット顎下腺果粒性膨大部、暗調果粒細胞 (DG) のみが図示されており，きわめて多数の 大暗調果粒を含む。小暗調果粒はその間に分散しており，明調果粒（矢印）は少数である。×4000

図22 正常雄ラット顎下腺排出管の明調円柱細胞の腺腔面に突出したアポクリン様突起 (AP). 細胞質 には多数の分泌果粒 $(\mathrm{SG})$ と系粒体 (M) が含まれている。 $\times 20000$

図23 去勢雄ラット顎下腺介在部. 腺房細胞 (AC) と介在部細胞 (ID) が共通の管腔（L）を囲む. 細 胞境界には多数の接着斑（D）があり，少数の分泌果粒を含む果粒細胞 (GC) が認められる。× 3600

図24 去勢雄ラット顎下腺介在部 (ID). 種々の方向に切れた筋上皮細胞 (ME) が見られる.周囲に腺 房細胞（AC）がある。 $\times 12000$ 

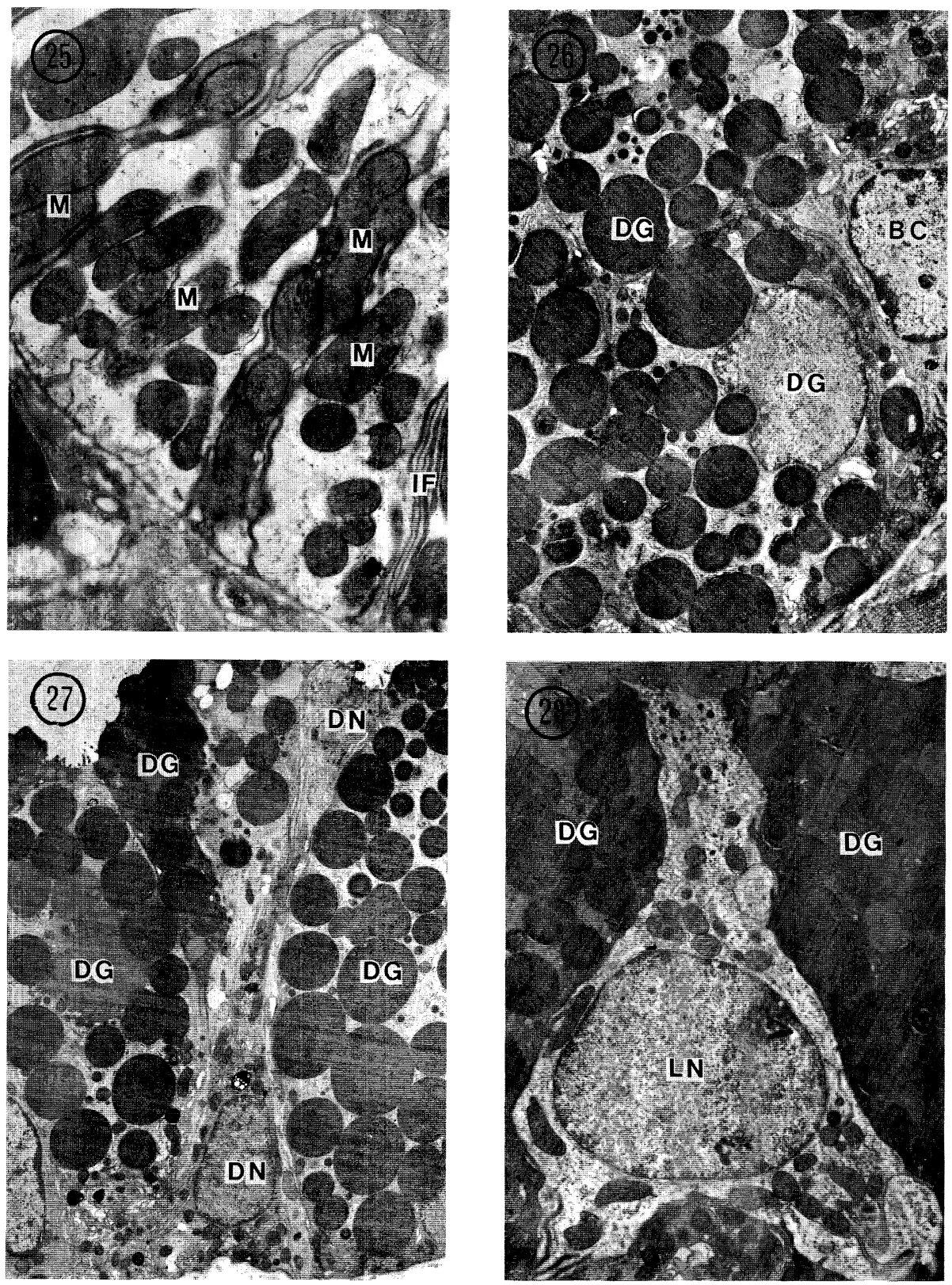

図25 去勢雄ラット顎下腺線条部細胞の基底線条。細胞膜の基底陥入 (IF) に亚行して, 多数の糸粒体 (M) が見られる． $\times 12000$

図26 去勢雄ラット顎下腺果粒性膨大部の暗調果粒細胞（DG） と基底細胞（BC)。 ×4000

図27去勢雄ラット顎下腺果粒性膨大部の暗調果粒細胞 (DG) に挾まれた細長い暗調狭細胞 (DN)。核 は基底部にあり，管腔面には微絨毛が少数認められる。×3600

図28 去勢雄ラット顎下腺果粒性膨大部の暗調果粒細胞 (DG) に挾まれた円錐状の明調狭細胞 (LN). 微小な暗調果粒を少数先端部に有する。 $\times 3600$ 

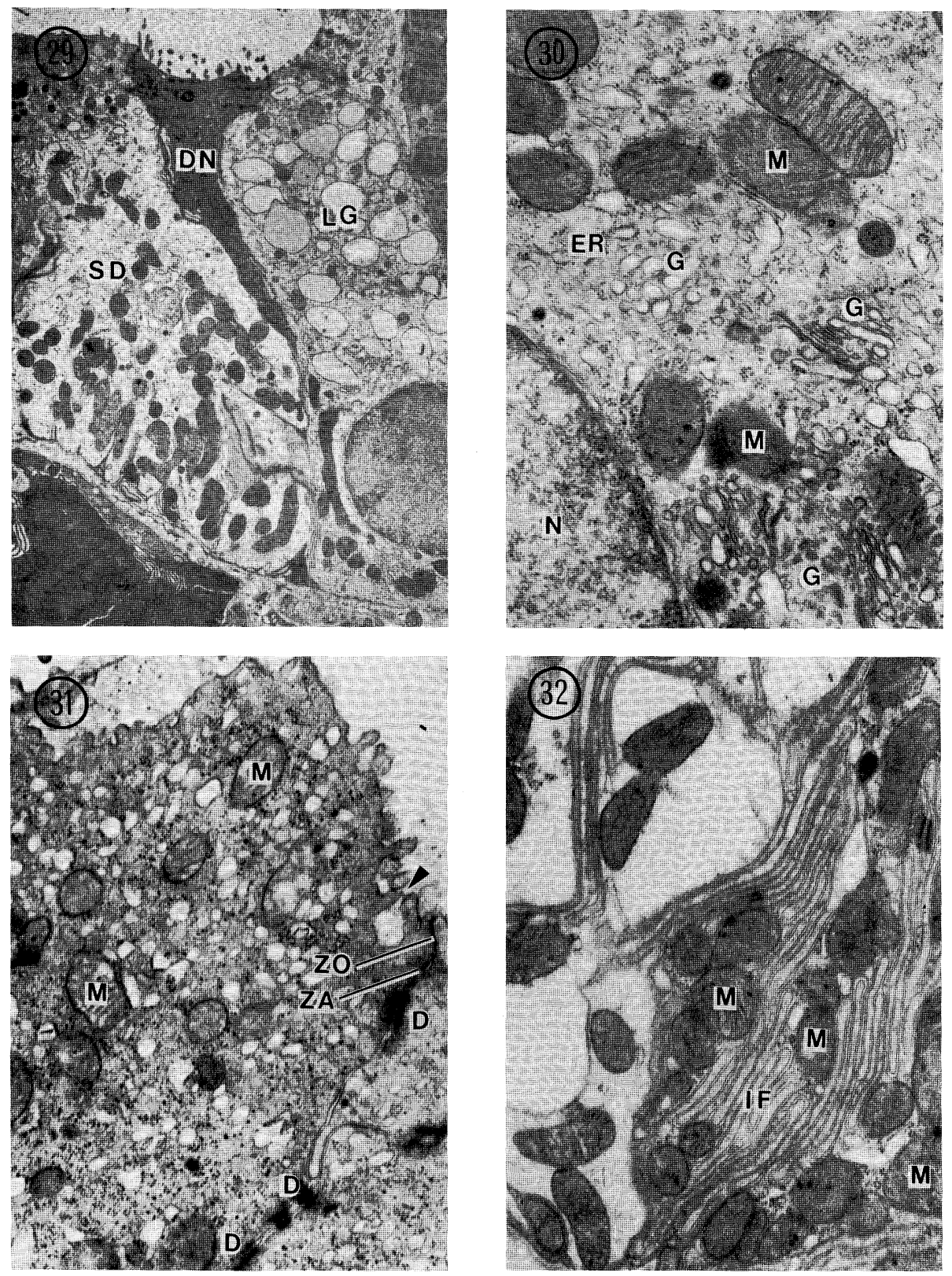

図29 去勢雄ラット顎下腺果粒性膨大部の明調果粒細胞 (LG) とこれに隣接する暗調狭細胞 (DN). そ の隣には混在した線条部細胞 $(\mathrm{SD})$ が見られる。 $\times 2800$

図30 去勢雄ラット顎下腺排出管の明調円柱細胞の核 $(N)$ の一部と核上部細胞質を示す。後者はよく 発達したゴルジ装置 $(\mathrm{G})$ ，分散型の粗面小胞体 $(\mathrm{ER})$ と糸粒体 $(\mathrm{M})$ を含む. $\times 13000$

図31 去勢雄ラット顎下腺排出管の暗調円柱細胞の先端部。系粒体 $(\mathrm{M})$ とリボゾームとともに多数の 小胞が存在する。この小胞は, おそらく内容を管腔に放出するのであろう。胞と管腔の連続し ている所を見ることができる (矢印). 細胞接触面に密着带 $(Z O)$, 中間带 $(Z A)$, および多数の 接着斑（D）から成る細胞間接着装置が発達している。 $\times 13000$

図32 去勢雄ラット顎下腺排出管上皮の基底部に見られる. 非常に上く発達した細胞膜の陷入 (IF) と, それにほぼ並行に並んでいる多数の糸粒体（M）を示す。 $\times 7600$ 
果粒は認められない。

\section{考}

唾液腺，特に顎下腺に雌雄間の性差が著しいこと

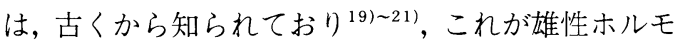
ン (testosterone) によって誘導されていることは, 多くの実験によって明らかにされたが1)，特にマウ スの顎下腺について行なわれた研究が多い。すなわ ち, Harvey ${ }^{16)}$ によると, マウス顎下腺の重量は雌よ りも，雄の方が優り，30日令の雌雄両方の幼若マウ スに testosterone を注射すると, 正常成熟雄の特徵 を示すようになり，gonadotropin の注射は35日令の 雄には有効であったが，雌には無効であった。 Atkinson ら ${ }^{3)}$ によると, 去勢による重量減少はマウ スの顎下腺において, 雌雄ともに起るが, 雌におけ るそれは主として水分の減少によるが，雄では水分 とともに乾燥組織成分も減少する.

Caramia $^{5)}$ によると，雄マウスを去勢すると顎下 腺の果粒性膨大部の体積が減少するが，電子顕微鏡 観察の結果, 去勢雄マウスの顎下腺は雌の特徵に一 致するようにならないことが明らかになった。 Smith と Frommer ${ }^{27)}$ によると, マウス顎下腺のア ミラーゼ活性は果粒性膨大部に限局しており，性的 に未熟なマウスを去勢したところ，生後60日での果 粒性膨大部におけるアミラーゼ活性は生後50日の 正常此に近似している。 また, Kaiho ら ${ }^{18)}$ は去勢マ ウスに testosterone を注射することにより，果粒性 膨大部の分泌果粒の数が完全に回復することを電子 顕微鏡所見により報告した。

Pinkstaff ${ }^{24)}$ は組織化学的にミニブタ (miniature pig）の顎下腺の性差が生後 3 週に発現することを 報告したが，それは特殊な例であって，大多数の哺 乳類では個体の性的成熟の後に，性差が発現する。 その点においては淎歯目の多くの動物も同様であ $ろ^{2117) 19) 23(28)}$.

また Dorey と Bhoola ${ }^{8) 9}$ によると, ハムス夕一顎 下腺の性差は導管系ばかりでなく，腺房細胞にも発 現するというが，他の多くの㹃歯目顎下腺の性差は 導管系にのみ発現するものである(1)11)13(15)22(23)27).

顎下腺の導管系のうち，最も腺房に近く，導管系 の初部をなす部分は介在部である。介在部は最も細 い導管の部分であるからここに性差が存在するか ぞうかは, 光学顕微鏡のみでは充分明らかにするこ とは不可能であった。江口 ${ }^{10)}$ はラット顎下腺につい
て, 生後 8〜10日で介在部の急激な成長が起り, 生 後15〜20日では介在部は減少して, 他の導管系が発 達して来ることを光学顕微鏡により観察した。 Tamarin と Sreebny ${ }^{30)}$ は電子顕微鏡観察の結果, 成 熟雄ラットの介在部には分泌果粒は存在しないとい う。しかし彼は雄のみを観察対照としているので, ラット顎下腺の介在部における性差は発見できな かった。

マウスの顎下腺では, Gresik ${ }^{12)}$ が電子顕微鏡によ り, 雌の介在部に分泌果粒を含む特殊な細胞の存在 することを発見し，これを granular intercalated duct cells（介在部果粒細胞）と呼んだ. 同じく電子 顕微鏡により Caramia $^{4) 5}$ は成熟マウスの介在部の 分泌果粒は雌にのみ存在し, 雄を去勢した場合でも, 介在部に分泌果粒は発現しないと報告している。後 にGresik と MacRae ${ }^{15}$ ) はマウスの雌雄両性とも胎 生期には介在部に分泌果粒を有するが, 生後には雄 では消失し，雌にのみ残存することを報告した。

筆者の所見では, Caramia ${ }^{4) 5)} に$ にるマウスの所見 および Tamarin と Sreebny ${ }^{30)}$ のラットにおける記 載と異なって, 雌雄両性ともに果粒細胞が存在し, 分泌果粒の大きさには雌雄差は認められなかった が, 細胞に含まれる分泌果粒の数は雌に比して, 雄 は極めて少く,去勢によってはさらに減少するので, 雄の去勢によって雌に近似することはなく，Cara$\mathrm{mia}^{5)}$ によって述べられたマウスの去勢の結果にほ ぼ一致する。

介在部に続く線条部の発生については, 電子顕微 鏡により, Cutler と Chaudhry ${ }^{7)}$ はラット顎下腺に ついて観察し, 胎生20日頃に線条部の初期像と考之 られる, 基底部細胞質の突起の認められる細胞が現 われ, 隣接する同種細胞の突起とからみ合い, 細胞 の成長とともに，突起は互いに圧迫されて，いわゆ る基底陥入の状態を示すようになる。この細胞は生 後 1 週間で完全な線条部に近い形になるという。さ らに Srinivasan とChang ${ }^{29)}$ は, 雄ラットの線条部 の顎下腺全体に占める比率は生後 4 週で最も高く, 以後成長するに従って低下し, 生後12週では半減に 近くなることを報告している。

筆者の所見では線条部の発達は雌の方が雄に優 り，雄の去勢によってもこの比率が変ることはな かった。線条部細胞の先端部に集積している分泌果 粒は正常雌に多く, 雌ではほとんどすべての細胞に 分泌果粒があるが, 正常雄では一部の細胞にのみ果 
粒が存在し, 大多数の線条部細胞には分泌果粒はな く，その代りに非常に小さな小胞が集っている. 去 勢による変化は軽微で, 暗調果粒は数, 大きさとも に正常雄と変らず, 明調果粒の数と大きさは正常雌 雄の中間に位する，線条部細胞の大きな特徵である 基底線条は, 正常雌において極哴く発達してい るのに対して, 正常雄では中等度である.去勢によっ てその発達は雌の状態に類似するようになるので, 線条部においても性差は著しく，去勢による影響は 軽いが, 明らかに存在するということができる。

果粒性膨大部は線条部から分化したものであり, マウス,ラット等において非常によく発達しており, 常に雄においてその発達は優位を占める。 マウス顎 下腺の性差に関する研究は非常に多く，その中の代 表的な文献については先に言及したが，ラットに関 しては, Shafer と Muhler ${ }^{26)}$ の研究がある.すなわ ち，ラットを去勢すると雌雄ともに顎下腺の果粒性 膨大部の大きさと数が減少するが, 雄ラットに testosterone (雄性ホルモン) を注射すると, 果粒性膨 大部の大きさと数が著明に増加するのに対して，雌 に diethylstilbestrol(雌性ホルモン)を注射すると果 粒性膨大部の数と大きさが減少することを光学顕微 鏡によって確めた。これによってラット顎下腺の果 粒性膨大部の発達が雄性 (男性) ホルモンに依存し ていることが明らかとなった。

ラット顎下腺の果粒性膨大部の発生に関して, Cutler と Chaudhry ${ }^{7)}$ によると, 生後 1 週のラット線条 部の近位部にある細胞の先端に空胞を生じ,この空 胞は生後 2 週で明らかな千モゲン様の分泌果粒に置 換され, 果粒性膨大部の初期像が現れる. 生後14週 では大量の分泌果粒が蓄積して, 果粒性膨大部は完 成に至る.しかし発生途上の果粒性膨大部細胞にも, 成熟した細胞にも微細構造上性差は認められないと 記している。

ラットの顎下腺の全般にわたって詳細な電子顕微 鏡的研究を行なった Tamarin と Sreebny ${ }^{30)}$ は, 実 験材料として雄のみを使用しているので, 性差につ いては全く触れていない。彼らは果粒性膨大部（果 粒管）の細胞を3種に分類して，1） Narrow agranular cell (無果粒狭細胞)，2） Light granular cell (明調果粒細胞)，3） Dark granular cell (暗調” 果粒細胞) と名付けた。彼らは狭細胞には分泌果粒 はないが, 細胞先端部に小胞状の明調果粒を有する と記載している。そして最も狭い細胞は細胞質が暗
調であるが，明調果粒細胞への移行型と考之られる 細胞があって, 果粒性膨大部の 3 種類の腺細胞は互 いに移行する 1 種類の細胞に他ならないと考えてい る.しなわち彼らの考えでは, 狭細胞 $(\mathrm{NC}) \rightarrow$ 明調果 粒細胞 (LG) ）暗調果粒細胞 (DG) と分化して行く と仮定した。

本論文において筆者は Tamarin と Sreebny ${ }^{30)}$ の 記載を参考にしつつ, 詳細に果粒性膨大部を観察し 雄ラットのみならず, 雌抒よび去勢雄ラットの同部 を観察した結果彼らの細胞分類に追加して，第 1 に 狭細胞を暗調狭細胞 (DN) と明調狭細胞 (LN) に分 け, 第 2 に基底細胞 (BC) を新たに加えた。基底細胞 はTamarin とSreebny ${ }^{30)} も$ 排出管において同種の 細胞を記載しているのであるが, 果粒性膨大部にも 存在することは気付いていなかったようである。こ の細胞は導管上皮の基底部に横たわっており, 細胞 先端が管腔に到達することはなく，また分泌果粒も 含まれていないから, 分泌機能は有しないものと思 われる。抏そらく未分化なまま成体にも保存されて いる幹細胞であって, 他の細胞型へ分化し得るもの と思われる。暗調狭細胞は細胞質が非常に暗く, 果 粒はきわめて少量しか含まないから, 基底細胞より 分化したばかりの幼若な分泌細胞であるか，あるい は暗調細胞が分泌果粒を放出してしまった残りの細 胞であるかもしれない。しかし種々の観点から前者 の可能性が高いものと思われる。明調狭細胞は暗調 狭細胞よりもやや細胞質も広く, 分泌果粒も常に見 出され, 明調果粒細胞への移行型と Tamarin と Sreebny $^{30)}$ が記載した細胞に一致する。他方果粒性 膨大部が觢歯目に特異的な導管部分であって, 他の 動物にも普遍的に存在する線条部から変って出来た ものであるという考えに従うならば, 明調狭細胞こ そ線条部細胞 (SD) から変化して生じた細胞ではな いかと思われる点が多く存在する。すなわち細胞先 端に小型の暗調な分泌果粒を含み, 基底部にわずか ながら隣接する細胞とかみ合う指状嵌合を有し退化 した基底線条を思わせる像を有する。すなわち明調 狭細胞は線条部細胞から移行し明調果粒へ行く途中 の細胞であるかもしれない。

ラットの顎下腺の各部の中で最も著明な性差を示 すのは果粒性膨大部であり, 雄は常に雌よりも優勢 である.去勢雄における筆者の所見では, 去勢によっ て暗調果粒の大きさは減少するものの, 暗調果粒細 胞の出現頻度はかえって増加し, 暗調果粒の最も増 


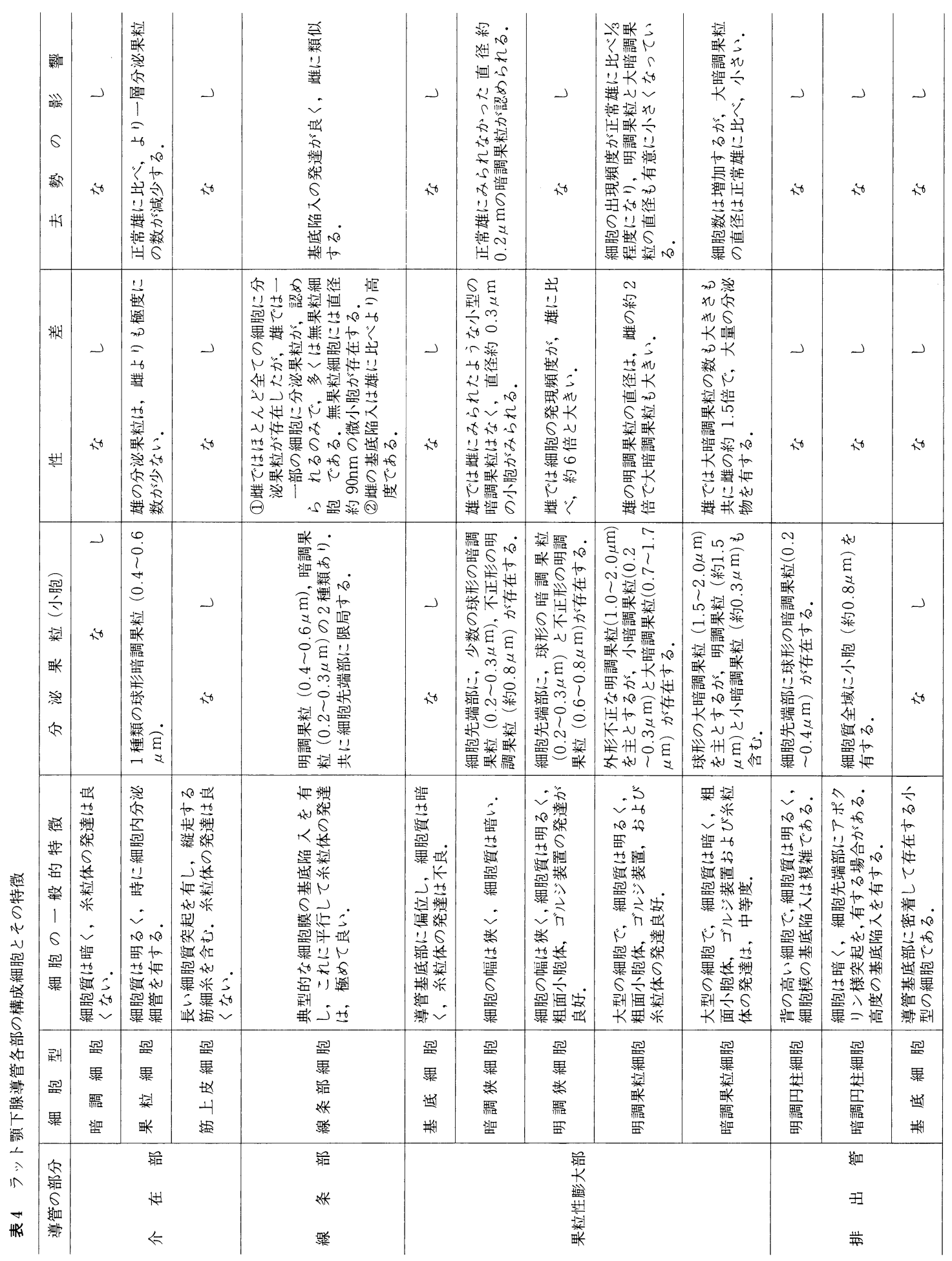


加している.しかし同時に明調果粒細胞の出現頻度 は激減して, かつ明調果粒の量は減少するので, 両 種果粒を合せた総量は多少の減少傾向を示すもの の, 有意の変化ではない.

Tamarinと Sreebny ${ }^{30)}$ は明調果粒細胞よりも暗調 果粒細胞の方が分化した細胞と考えているが，Cutler と Chaudhry ${ }^{6)}$ によると分泌刺激を与えられた果 粒性膨大部細胞は分泌果粒が空胞化して融合し, 逆 に管腔へ向って開口放出 (exocytosis) すると記載し ており，また Young と van Lennep ${ }^{31)} も$ 明調果粒細 胞に最も頻繁に chain exocytosisによる果粒放出が みとめられ, Tamarin と Sreebny ${ }^{30)}$ の考えに反し て, 明調果粒細胞が最も成熟した細胞型であると記 している。この考え方に従えば，雄ラットを去勢す ることによって，果粒性膨大部細胞の分化が抑えら れて, 暗調果粒細胞の段階でとどまる細胞がふえた のかもしれないと解することができる。すなわち筆 者は Tamarin ら ${ }^{30)}$ の考之と異なり, 果粒性膨大部 の細胞の分化を次のような 2 系列の経過によると仮 定したい，a）基底細胞 $\rightarrow$ 暗調狭細胞 $\rightarrow$ 暗調果粒細 胞 $\rightarrow$ 明調果粒細胞. b ) 線条部細胞 $\rightarrow$ 明調狭細胞 $\rightarrow$ 明 調果粒細胞.

導管系の最終部である排出管の構成細胞は Tamarin とSreebny ${ }^{30)}$ によって次の 3 種に分類された. 1) Tall columnar light cell (明調円柱細胞)，2） Tall dark vesiculated cell (暗調小胞細胞)，3） Small basal cell (小型基底細胞). Shackleford と Schneyer ${ }^{25)}$ はやはりラットの排出管を観察して, 同 様に 3 種に分類したが, さらに簡単に，1） Light cell，2） Dark cell, 3） Basal cell と呼んだ.筆者 もこれらの分類を参考にして1）明調円柱細胞，2） 暗調円柱細胞，3）基底細胞と分類した。しかし排出 管に関する性差および去勢の効果については明確な 結論を得るに至っていない。

\section{要約}

ラット顎下腺の導管系に出現する性差ならびに雄 ラットの去勢による変化を研究するために, 成熟此, 雄ラットおよび去勢後 4 か月の雄ラットの顎下腺を 透過電子顕微鏡によって観察し, 電子顕微鏡写真に ついて, 導管各部の大きさ, 各部構成細胞の微細構 造，特に分泌果粒の直径および面積を計測して，比 較検討を加えた。

1.ラット顎下腺の導管系は, 介在部, 線条部,
果粒性膨大部および排出管に分けられる.介在部は 暗調細胞, 果粒細胞, 筋上皮細胞からなる。線条部 はただ 1 種類の線条部細胞によって構成される. 果 粒性膨大部の細胞は基底細胞, 暗調狭細胞, 明調狭 細胞, 明調果粒細胞, 暗調果粒細胞の 5 型に分類さ れる。排出管には, 明調円柱細胞, 暗調円柱細胞, 基底細胞の 3 型が存在する。

2. 介在部の果粒細胞には, 雌雄両性とも分泌果 粒が認められるが, その数は雌に比べて雄では極め て少く，去勢によってさらに減少する.

3. 線条部の発達は雌の方が雄に優り, 雌では, ほとんどすべての細胞に分泌果粒が存在するが, 雄 では一部の細胞に分泌果粒が存在するのみである。 雄の無果粒細胞には, 細胞先端部に小胞が集ってい る. 線条部細胞の特徵である基底線条は雌の方が雄 に優っている，去勢による変化は軽微であるが雌に 類似するようになる.

4. 果粒性膨大部の分化は以下の 2 采列が考えら れる。ａ）基底細胞 $\rightarrow$ 暗調狭細胞 $\rightarrow$ 暗調果粒細胞 $\rightarrow$ 明調果粒細胞. b ) 線条部細胞 $\rightarrow$ 明調狭細胞 $\rightarrow$ 明調果 粒細胞.

5. 果粒性膨大部は, ラット顎下腺の各部の中で 最も顕著な性差を示す部分である，雄は常に雌より 優位である. 去勢によって果粒性膨大部細胞の分化 が抑えられて, 未分化型と考えられる暗調果粒細胞 の出現頻度は増加するが, 逆に最も成熟した細胞型 と考えられる明調果粒細胞の出現頻度は激減して, さらに明調果粒の量も減少する。

6. 排出管については, 性差と去勢の効果は明ら かでない.

謝辞

稿を終るにあたり，終始御指導と御校閲を賜わりました恩 師黒住一昌教授に謹しんで感謝の意を表するとともに，御協 力いただいた井上金治博士，斉藤文雄技官および教室員各位 に深謝いたします。

\section{文献}

1) Angeletti, P.U. and Angeletti, R.: Androgen-dependent esterase activity in the mouse submaxillary gland. Biochim. Biophys. Acta, $136: 187-189,1967$.

2) Arvy, L., Debray, Ch. et Gabe, M. : Action de la thiourée sur la glande sous-maxillaire du 
rat albinos. C. R. Soc. Biol., 144:111-113, 1950.

3) Atkinson, W.B., Wilson, F. and Coates, S. : The nature of the sexual dimorphism of the submandibular gland of the mouse. Endocrinology, $65: 114-117,1959$.

4) Caramia, F. : Ultrastructure of mouse submaxillary gland. I. Sexual differences. J. Ultrastruct. Res., 16:505-523, 1966.

5) Caramia, F.: Ultrastructure of mouse submaxillary gland. II. Effect of castration in the male. J. Ultrastruct. Res., $16: 524-536,1966$.

6) Cutler, L.S. and Chaudhry, A.P. : Release and restoration of the secretory granules in the convoluted granular tubules of the rat submandibular gland. Anat. Rec., $176: 405-420$, 1973.

7) Cutler, L.S. and Chaudhry, A.P. : Cytodifferentiation of striated duct cells and secretory cells of the convoluted granular tubules of the rat submandibular gland. Am. J. Anat., 143 : 201-218, 1975.

8) Dorey, G. and Bhoola, K.D. : I. Ultrastructure of acinar cell granules in mammalian submaxillary glands. Z. Zellforsch., 126:320-334, 1972.

9) Dorey, G. and Bhoola, K.D. : II. Ultrastructure of duct cell granules in mammalian submaxillary glands. Z. Zellforsch., 126 : 335-347, 1972.

10）江口正昭： ラット唾液腺の加齢的変化に関す る組織学的研究. 九州歯会誌. $28: 459-484$, 1975.

11) Flon, H., Gerstner, R., Mitchell, O.G. and Feldman, A. : Salivary glands of heteromyid rodents, with a summary of the literature on rodent submandibular gland morphology. J. Morph., 131 : 179-194, 1970.

12) Gresik, E.W. : A previously unreported cell type in female mouse submandibular glands. J. Cell Biol., 31 : 144A, 1966.

13) Gresik, E.W. : The postnatal development of amylase activity in the submandibular glands of the mouse. Anat. Rec., 154:351,
1966.

14) Gresik, E.W. : Postnatal developmental changes in submandibular glands of rats and mice. J. Histochem. Cytochem., $28: 860-870$, 1980.

15) Gresik, E.W. and MacRae, E.K. : The postnatal development of the sexually dimorphic duct system and of amylase activity in the submandibular glands of mice. Cell Tiss. Res., $157: 411-422,1975$.

16) Harvey, H. : Sexual dimorphism of submaxillary glands in mice in relation to reproductive maturity and sex hormones. Physiol. Zool., 25 : 205-222, 1952.

17) Junqueira, L.C., Fajer, A., Rabinovitch, M. and Frankenthal, L. : Biochemical and histochemical observations on the sexual dimorphism of mice submaxillary glands. J. Cell. Comp. Physiol., 34:129-148, 1949.

18) Kaiho, M., Nakamura, T. and Kumegawa, M. : Morphological studies on the synthesis of secretory granules in convoluted tubules of mouse submandibular gland. Anat. Rec., 183 : 405-420, 1975.

19) Lacassagne, A. : Dimorphisme sexuel de la glande sous-maxillaire chez la souris. C. R. Soc. Biol., 133 : 180-181, 1940.

20) Lacassagne, A.: Mesure de l'action des hormones sexuelles sur la glande sous-maxillaire de la souris. C. R. Soc. Biol., 133:227 $-229,1940$.

21) Lacassagne, A.: Réactions de la glande sous-maxillaire a l'hormone male, chez la souris et le rat. C. R. Soc. Biol., 133 : 539-540, 1940.

22) Mudd, B.D. and White, S.C.: Sexual dimorphism in the rat submandibular gland. J. Dent. Res., $54:$ 193, 1975.

23) Odajima, M. : Ultrastructure and histochemistry of the submandibular gland of the Japanese wood mouse (Apodemus ainu ainu Tokuda). Arch. Histol. Jap., 44 :385-400, 19 81.

24) Pinkstaff, C.A. : Sexual dimorphism of the 
miniature pig submandibular glands. Am. J. Anat., 135:371-380, 1972.

25) Shackleford, J.M. and Schneyer, L.H. : Ultrastructural aspects of the main excretory duct of rat submandibular gland. Anat. Rec., $169: 679-696,1971$.

26) Shafer, W.G. and Muhler, J.C. : Effect of gonadectomy and sex hormones on the structure of the rat salivary glands. J. Dent. Res., 32 :262-268, 1953.

27) Smith, R.J. and Frommer, J.: Effects of prepubertal castration on development of granular tubules and amylase activity in the male mouse submandibular gland. Arch. Oral. Biol., $17: 1561-1571,1972$.

28) Sreebny, L.M., Meyer, J., Bachem, E. and
Weinmann, J.P. : Postnatal changes in proteolytic activity and in the morphology of the submaxillary gland in male and female albino rats. Growth, $19: 57-73,1955$.

29) Srinivasan, R. and Chang, W.W.L. : The development of the granular convoluted duct in the rat submandibular gland. Anat. Rec., 182 : 29-40, 1975.

30) Tamarin, A. and Sreebny, L.M. : The rat submaxillary salivary gland. A correlative study by light and electron microscopy. J. Morph., 117 : 295-352, 1965.

31) Young, J.A. and van Lennep, E.W. : The morphology of salivary glands. 1st. ed., Academic Press, New York, 1978, p. 72-113.

\title{
MORPHOLOGICAL AND MORPHOMETRIC STUDIES ON THE FINE STRUCTURE OF DUCT SYSTEMS OF THE SUBMAN- DIBULAR GLANDS IN NORMAL AND CASTRATED RATS AS REVEALED BY ELECTRON MICROSCOPY.
}

\section{IZUMI SHIBUICHI}

\author{
Department of Morphology, Institute of \\ Endocrinology, Gunma University, Maebashi, Japan \\ (Director: Prof. Kazumasa Kurosumi)
}

The sexual dimorphism and the effects of castration on the duct system of the rat submandibular glands were studied with the transmission electron microscope. Not only the simple observation of fine structure, but also morphometric measurement of various inclusions and elements of the constituent cells of the duct system were performed.

1. The duct system of the rat submandibular gland consists of the intercalated duct, striated duct, granular duct and excretory duct. The intercalated duct contains three cell types; dark cell, granulated cell and basal cell. The striated duct is composed of only one cell type that is called striated duct cell, though its cytoplasm varies in electron density from cell to cell. The constituent cells of the granular duct are classified into five types in this paper as follows : basal cell, dark narrow cell, light narrow cell, light granular cell, and dark granular cell. The excretory duct consists of three types of cells ; light columnar cell, dark columnar cell and basal cell.

2. The granulated cells of the intercalated duct contain secretory granules in both sexes, but the number of granules predominates in female over male glands. The castration of male rats causes the decrease of granule number in this cell type. 
3. The development of striated duct is better in female than in male. Almost all cells of the striated duct of female rats contain secretory granules, but in male non-granulated cells predominate over the granulated cells. Instead of granules, there are very small vesicles in the apical part of the non-granulated cells of the male striated duct. The effect of castration is slight in this part of the duct, but the appearance of cells after castration is a little similar to the case in female.

4. The two courses of differentiation of epithelial cells of the granular duct were assumed : a) basal cell $\rightarrow$ dark narrow cell $\rightarrow$ dark granular cell $\rightarrow$ light granular cell, b) striated duct cell $\rightarrow$ light narrow cell $\rightarrow$ light granular cell.

5. The granular duct shows most conspicuously the sexual dimorphism among various parts of the rat submandibular gland. The male granular duct always predominates over the female duct. Castration may inhibit the differentiation of cells in the granular duct, resulting in the decrease in volume of light granules as well as the number of light granular cells, that is thought to be the most differentiated type of the cells. The number of dark granular cells was increased, probably as the result of inhibition of differentiation from the dark granular cells into light granular cells.

6. The sexual difference as well as the effect of castration was vague in fine structure of cells in the final part of the duct system, that is the excretory duct.

Key words: Submandibular gland, Sexual dimorphism, Castration, Duct system, Electron microscopy. 